\title{
DÜBLIN
}

Technological University Dublin ARROW@TU Dublin

\section{When attitudes became toys: Jasia Reichardt's play orbit}

\author{
Tim Stott \\ Technological University Dublin, tim.stott@tudublin.ie
}

Follow this and additional works at: https://arrow.tudublin.ie/aaschadpart

Part of the Art and Design Commons

\section{Recommended Citation}

Stott, T. (2018), When Attitudes Became Toys: Jasia Reichardt's Play Orbit. Art History, 41: 344-369. DOI: 10.1111/1467-8365.12329

This Article is brought to you for free and open access by the Fine Arts at ARROW@TU Dublin. It has been accepted for inclusion in Articles by an authorized administrator of ARROW@TU Dublin. For more information, please contact arrow.admin@tudublin.ie, aisling.coyne@tudublin.ie,gerard.connolly@tudublin.ie.

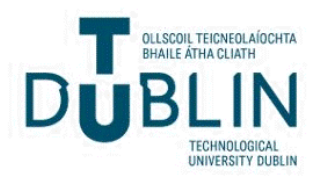




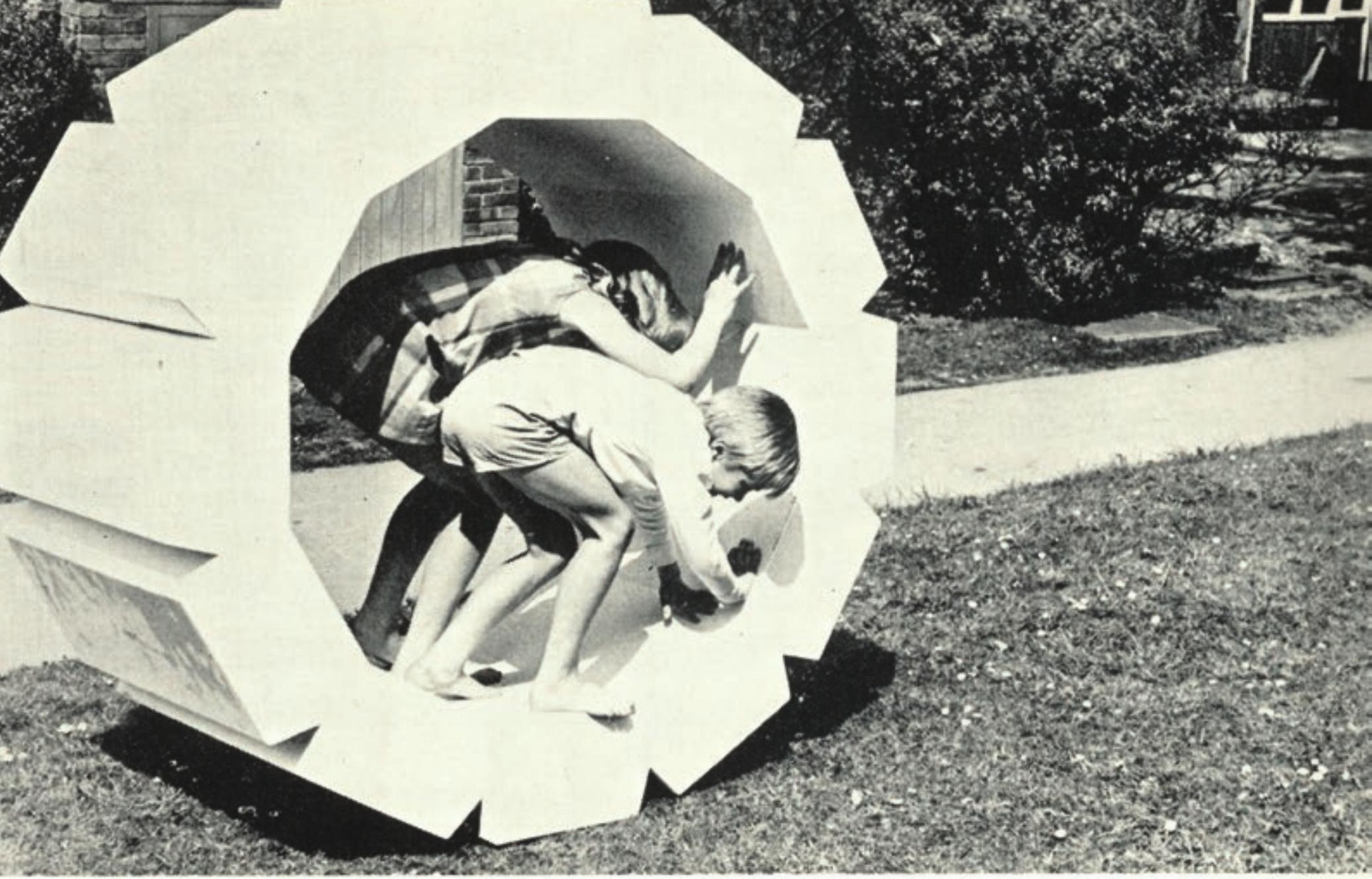




\section{When Attitudes Became Toys: \\ Jasia Reichardt's Play Orbit}

Tim Stott

Detail of Guildford School of Art (Calvin Lucas, Philip Gregory, Kenneth Ansell),

Rotating Land/Water Toy,

1969, and Guildford School of

Art (Raymond Duns, Janine

Cairns, Tom Saddington),

Eccentric-Movement Activity

Toy, 1969 (plate 5).

DOI:

|0.1|||//467-8365.12329

Art History | ISSN 0141-6790

41 | 2 | April 2018 | pages 344-369
'The most democratic exhibition ever held in this country.' This was how Jasia Reichardt, then Assistant Director of the Institute of Contemporary Arts in London, introduced Play Orbit (plate 1), an exhibition of 'toys, games, and playables [produced] by people who are not professionally involved with the design of playthings, but who work in the field of the visual arts.' Play Orbit was curated by Reichardt in collaboration with Peter Jones of the Welsh Arts Council and first shown at the Royal National Eisteddfod of Wales in Flint from 4 to 9 August 1969 and then at Nash House, London, home of the ICA, from 28 November 1969 to 15 February 1970. Its democratic credentials derived, Reichardt believed, from its open invitation for submissions, without jury selection (the submissions were limited only by a maximum size of six feet in any direction) which encouraged students and early-career or marginal artists. Furthermore, many of its playthings required visitors to the exhibition to engage with them directly, to build, shake, twist, balance, roll, spin, sort, and so on. Such ludic explorations were hitherto excluded from the space of public exhibition, and to now encourage them was, in Reichardt's view, a democratic gain.

This claim notwithstanding, Play Orbit's introduction of play participation into the space of art exhibition certainly changed the nature of the works available to the public, a change, that is, in what type of thing the work of art was or could be and what manner of engagement it required as a result. This ontology privileged performance over representation, as, in most cases, a player was to learn what a toy did, rather than, say, what it stood for.

The argument that I wish to develop here is that the ontology introduced by Play Orbit's toys, games and playables was a cybernetic one. Many of them were, to use an engineering term central to cybernetics, Black Boxes, each a system of variables with which one might play without full knowledge of its internal mechanisms and which might behave in an unpredictable manner as a result. The details of this ontology, and its significance to an analysis of Play Orbit, will be discussed below. If my argument stands, what was at the time an unprecedented exhibition of toys, games and playables actually marks a significant moment in the history of systems art, which grew through the artistic encounter with cybernetics in the late 1960s and at the forefront of which was the earlier and better-known exhibition, Cybernetic Serendipity, also curated by Reichardt at the ICA from 2 August to 20 October 1968. In fact, aside from obvious differences in content - an exhibition of toys, on the one hand, and an exhibition of computers and machines, on the other - Play Orbit and Cybernetic Serendipity appear to share this cybernetic ontology. Most importantly, the later exhibition 


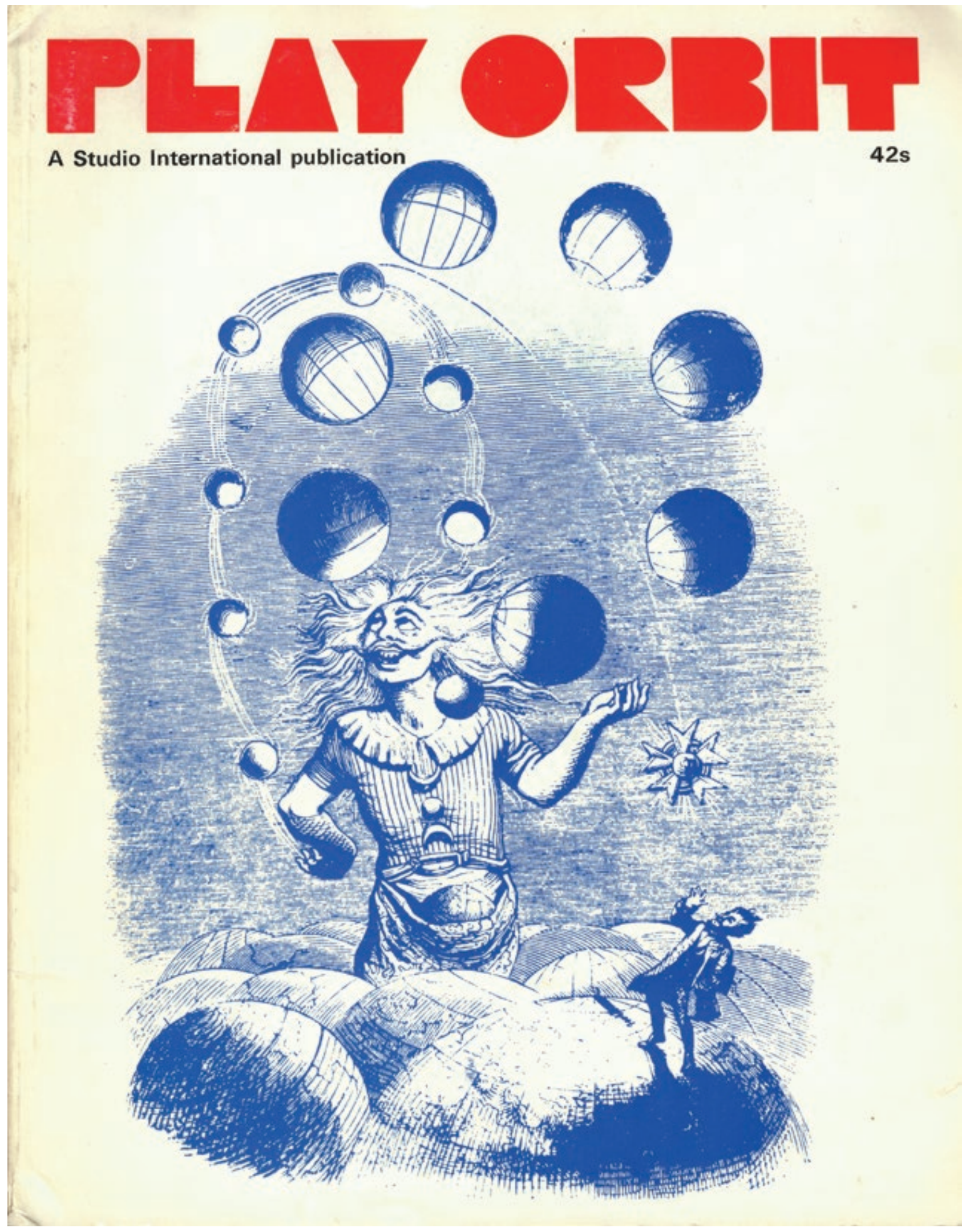

expanded this ontology to the social domain of play, beyond cybernetics' initial applications in engineering, computing, and psychiatry, applications that the earlier exhibition confirmed without question. In doing so, Play Orbit both works through 
I Jean-Ignace Gérard dit Grandville, illustration from Un Autre Monde, Fournier, Paris, 1844, published in England as a Christmas card by Gaberbocchus Press. Jasia Reichardt and Peter Jones, Play Orbit, exhibition catalogue, Studio International, special issue, 1969/70, front and back covers. the social implications of cybernetics and challenges the idealization of play in postwar British culture as a humanist corrective to a cybernetics-driven technocracy. Yet, although the impact of cybernetics upon cultural practice at this time has now become the object of scholarly interest, little attention has been given to its social dimension in general and to the importance of play and participation in particular. ${ }^{2}$

\section{The Exhibition}

Play Orbit belongs to a small but art-historically significant group of exhibitions of the late 1960s that invited visitors to engage in what Reichardt called, in her introduction to the exhibition catalogue, 'play participation' (8). Despite the occasional mayhem and destruction that resulted from the introduction of play to the spaces of public arts exhibition at that time, for many play offered the ideal means to explore and intensely experience then current transformations in the exhibition environment and its contents. ${ }^{3}$ In Reichardt's view, developments in 'a narrow periphery of painting, sculpture, and other activities developed from, or associated with them' made an exhibition such as Play Orbit possible (7). ${ }^{4}$ The initial idea for an exhibition of toys derived from American curator and critic Gene Baro, who believed the subject of play would appeal to artists who had abandoned traditional media (7).

As it turned out, in most cases the puzzles, games, and toys on display were only tenuously connected to developments in painting and sculpture, and Reichardt herself was reluctant to describe them as works of art at all, even as some were still isolated and protected in the manner of museum artefacts. Her ambition for the exhibition was to collapse the false distinction between works of art and 'those other things which fill our environment, fulfil our spiritual needs, and which, for arbitrary reasons, don't have such elevated titles' (7). An exhibition of this sort was, for Reichardt, 'more significant and interesting as a sociological phenomenon than a homogeneous aesthetic one' (7), which is to say that it was significant for the sociability encouraged by the toys. ${ }^{5}$ Some failed on this account. The criterion of playability appeared as strict and demanding as more conventional artistic criteria. Many of those who initially agreed to contribute later withdrew from the exhibition, Reichardt wrote, 'stating frankly that their ideas were not good enough' (8). Those who did exhibit displayed, as Jonathan Benthall observed in his review of the exhibition, 'a rather unusual humility. ... Children do inspire humility.' ${ }^{6}$

Reichardt asked contributors 'What is a Toy?' On the basis of their answers, she identified four categories. The first of these was that a toy 'must involve participation in its construction'. The second category was that a toy is pleasurable and a 'depository for the imagination'. Third, a toy is a manipulable environment. Fourth, a toy is an object 'with which we can simulate real-life situations' (8). These categories covered submissions to the exhibition that ranged from the frivolous to the occult to the pedagogical, and included praxinoscopes, building blocks, modified chess games, generic play objects, puzzles and mazes, puppets, and kinetic toys. Many contributors exploited a toy's capacity for vast combinatory possibilities, such as Peter Hobbs' Multiple No.3, a three-part construction that, according to the artist, offered '46,656,000 compositions'? Similarly, Roy Grayson's System - A Postal Toy for Executives consisted of a kit of twelve cut-out mail order systems that could be assembled as 'part of a number of interchangeable and variable images which are displayed in a Perspex case', and there was Jasper Sewett's Jigsaw Puzzle with 'twenty-five symmetrical double-sided interlocking pieces [that] can be arranged in over 12,000,000 ways'. Some contributions made explicit the correspondence between a toy and recent developments in artistic production. Bernard Bertschinger described his Topless Boxes 


\section{Bernard Bertschinger, Topless Boxes, 1969. Seven wooden boxes, from $60 \times$ $46 \times 23 \mathrm{~cm}$ to $30 \times 22 \times 15 \mathrm{~cm}$. Photos: Don Flowerdew. Jasia Reichardt and Peter Jones, Play Orbit, exhibition catalogue, Studio International, special issue, 1969/70, III.}

\section{Bernard Bertschinger}

Topless boxes

Prying is imenting. a tor is the taw material.

A tov is - for fun

-for laeming

- for teaching

Topless Bams-a do-it-yourseff-multipie.

minmalvart-play -kot. is easentially for fun
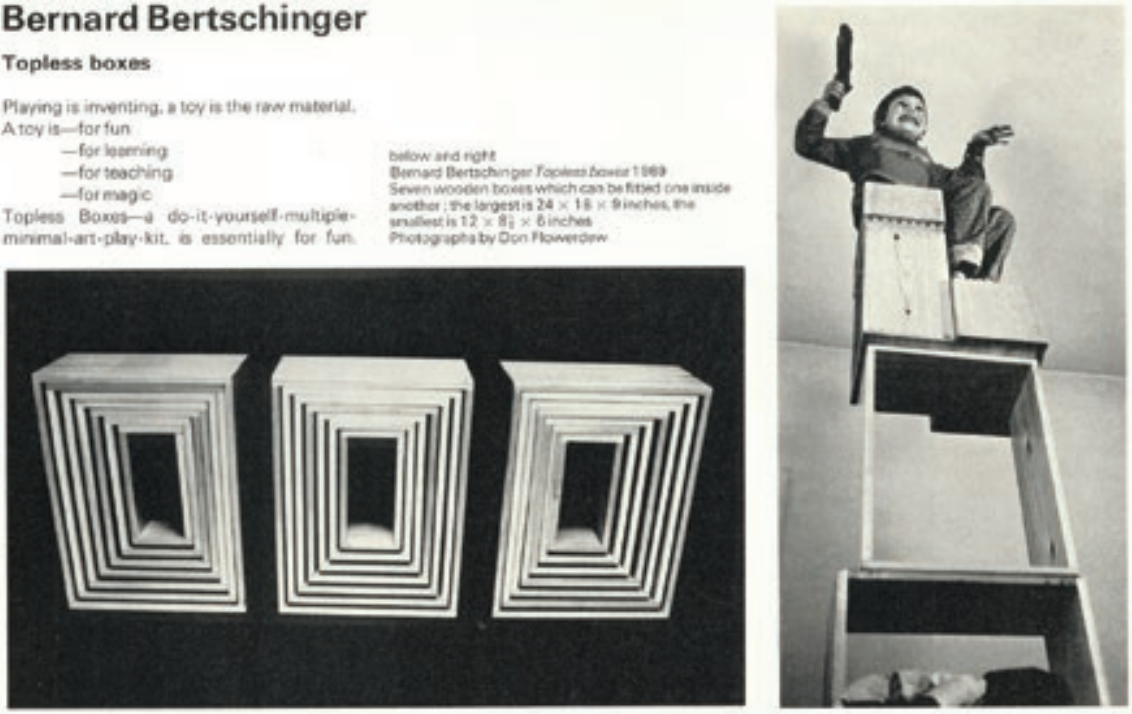

\section{Oliver Bevan}

\section{Connections}

Any question sbout tovs irrotwes an under. standing of playing-an actinty not mereh. confined to children. Human bengs maintar their plary dive in adit lfo much more thes otever animals kcoending to Dasmond Morris elaving teems to be beth dismeretied and passionere at the same bime - dininterersed in that if't not foc thel, and pusionate in the that ifs not foe rabl, and sassionate in the

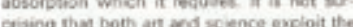

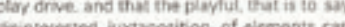

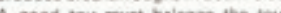
A good toy must balsweo the toy-makar: Inverinveritar wainst the plapers inventive.

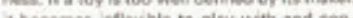
4 tecomes mancle to ptay with and con. secosindy boring. it on the bos thend, it as too loosoly datined it wir tail to provise the stimului nocessery to make is werth pinving with. As an exemple of this balance of leck. a: I has two buibing sets as a child. cne of which was highly realistic with limle brick and imitation mortar; it hed blueprints to work frem. I pot as ter as ab bua sheher with wobbly wells. The ocher wot consittid of a eabiner-meker's offeculs slaned down to standesd units it was ideal: nufficiently

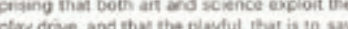

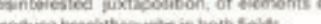

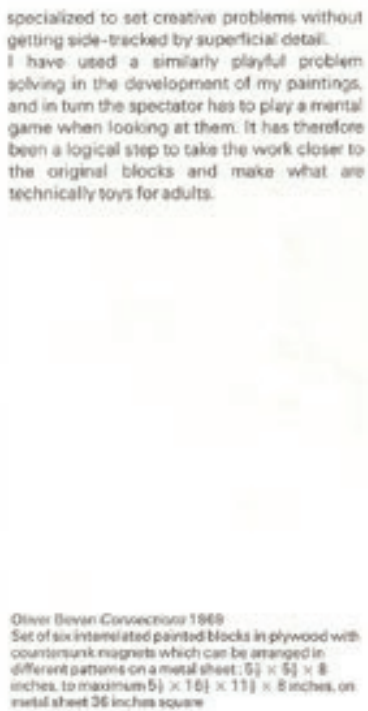

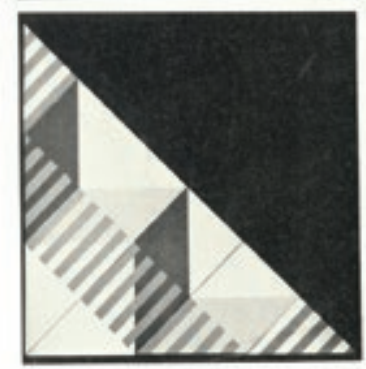

(plate 2) as a 'do-it-yourself-multiple-minimal-art-play-kit', and thereby aligned it with the use of 'sets, series, modules, permutations, or other simple systems' that, for Robert Morris, characterized minimalist sculptural construction. ${ }^{9}$ The crucial additions made by Bertschinger are, quite clearly, a do-it-yourself approach and play (and in doing so he predates by over a year Morris's own working through of the consequences of minimalist sculpture toward play and participation in his retrospective at the Tate Gallery in 1971). Elaborating upon a quite different set of artistic strategies from Dada wordplay to concrete poetry, Edwina Leapman's Proverbial Disc was, 'a rotating disc with a flat ring each containing halves of seventy-two proverbs which can be associated at random.' ${ }^{10}$ Consistent with the first category, many toys, such as Topless Boxes and Jigsaw Puzzle, required further construction by participants. Others belonged to the third category, like Ron Dutton's Elasticlimb (plate 3). Evidently, toys in these categories belonged also to the second, as they appeared to be the most popular, especially with children. 


\footnotetext{
3 Ron Dutton, Elasticlimb, 1969. Steel and rubber climbing frame, $183 \times$ $183 \times 183 \mathrm{~cm}$. Photo: Don Flowerdew. Jasia Reichardt and Peter Jones, Play Orbit, exhibition catalogue, Studio International, special issue, 1969/70, II4.
}

The ICA encouraged participation wherever possible. In an undated letter sent prior to the opening of Play Orbit, Juliet Brightmore reminded contributing artists that the Institute was anxious that their toys 'should be played with and touched, rather than only looked at'. Some might be damaged as a result, she warned, therefore each contributor was given the option to recommend his or her toy for one of three sections according to its robustness. In the first, 'Museum Section', exhibits were 'either fragile or very small' and would not be touched. The second, B Section was 'a gaming area where older children and adults can play with puzzles and construction games, with a croupier in attendance'. The final, C Section was 'a participation area where visitors will be invited to play with the toys and games. ${ }^{11}$ Concurrent with Play Orbit at the ICA, but not at the Eisteddfod, there were a number of plays provided for and sometimes involving children, as well as puppet shows such as Barry Smith's Theatre of Puppets which ran a twice-daily programme from 20 to 24 January 1970 in the ICA exhibition space. ${ }^{12}$

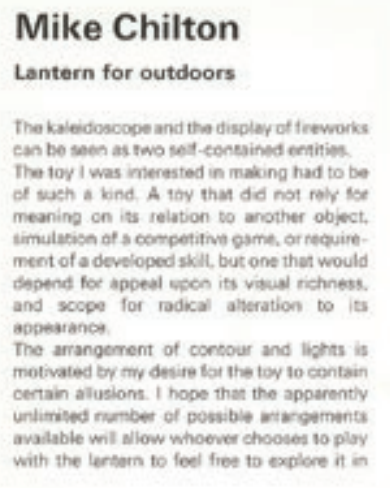

\section{Ron Dutton \\ Elasticlimb}

A toy is I stuation which enables the earbegatsojoperator to pamp neld of mental/chrsical state wich makes tim larget than life.

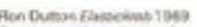

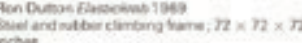

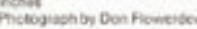

\section{H. Eastwood}

\section{The time machine}

My interpretation of the toy is not necessarily anything you can touch. When I was a chily $\mathrm{my}$ greatest trest was to look at a glas: eabinet with fascinating snuff boses, fani coins. exc. The game was to conjure up the people who had und the inulf boures, waves the tans, of chinkod the coins. so they Eecumerival toys torne

The ides of the Time Machine is than every. body in the room should de detribe the nen. coistient witch string on the srool. The ane who products the beat deacription of gets

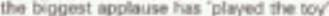

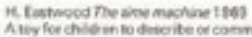

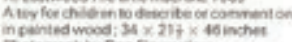
114

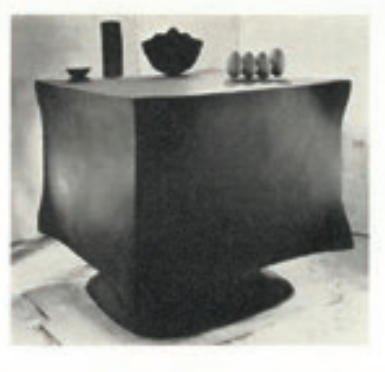

any way appesing to their imagination. The tanteen consists of of translucant ficre gisss and metel box moumed ucon a base. 48 inches high and iust over 48 incties across
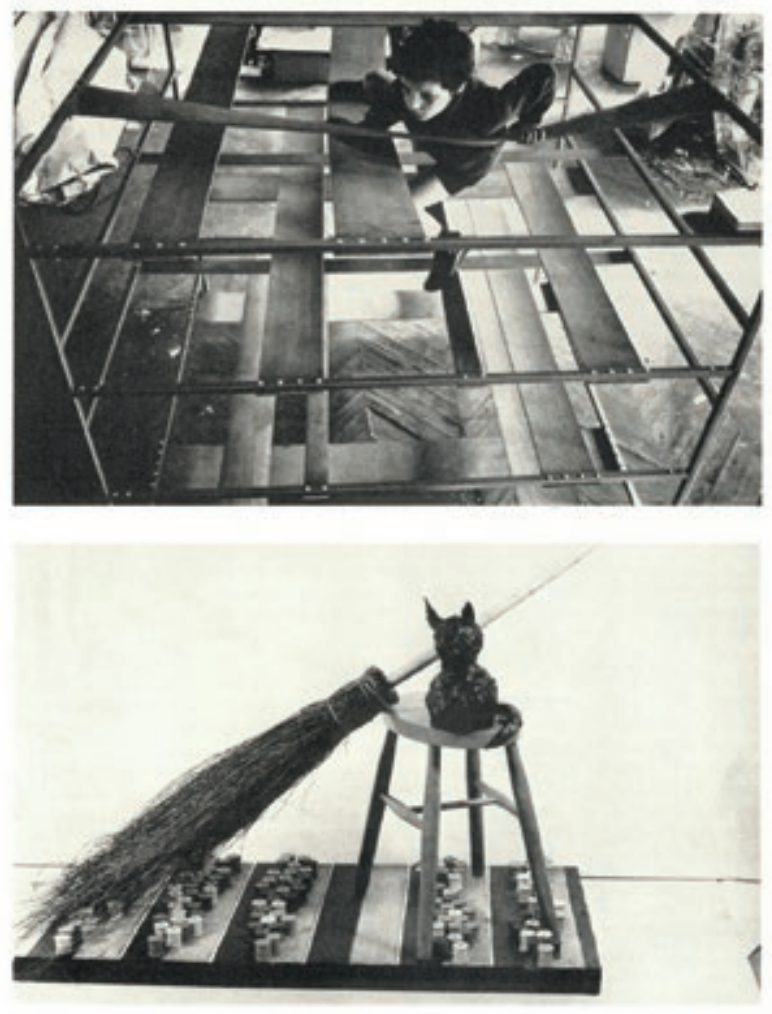


\section{L'esprit cybernétique}

As noted above, Play Orbit's introduction of play participation within a public art exhibition correlated to a change in what type of thing the work was or could be and what manner of engagement it required as a result. The ontology of works in Play Orbit was one that privileged performance over representation, or what things do over what they might stand for. After all, the toys and playables were primarily of interest in play, where, through manipulation and feedback, players learnt what a toy did and what they could do with it. Taking its cue from Andrew Pickering's monograph The Cybernetic Brain: Sketches of Another Future from 2010, the principal claim of this essay is that the ontology of Play Orbit's toys was a cybernetic one. ${ }^{13}$ As noted, this would mean that Play Orbit follows on from Cybernetic Serendipity. The latter sought 'connexions between creativity and technology (and cybernetics in particular)', whereas Play Orbit tested what a toy might be by much less technologically sophisticated means and was not related explicitly to the field of cybernetics. ${ }^{14}$ Nonetheless, the two exhibitions shared a participatory and ludic mode of address to their visitors. As Maria Fernandez argues, both 'encouraged visitors to interact with nonhuman entities (objects and machines) and interrogated the boundaries between pleasure and play'. ${ }^{15}$ Judged by media reaction at the time, the principal achievement of Cybernetic Serendipity was to show that visitors could interact with computers and machines through play. Leslie Stack of the ICA proclaimed that 'We want people to lose their fear of computers by playing with them and asking them simple questions. ${ }^{16}$ Both operated in an exhibitionary mode consistent with Reichardt's demonstrated and longstanding interest in the encounter between cybernetics and art, a mode in which play organizes an interactive, self-regulating relationship between an assembly (which might be a computer or a toy) and its observers.

However, Reichardt has cast doubt upon any connection between the two exhibitions, meaning that the extent to which cybernetics influenced her curatorial commitments and decision-making beyond her longstanding interest in computing and information technologies remains unclear. ${ }^{17}$ Yet the meeting of cybernetics and art at the time had prompted what Roy Ascott called, in a two-part essay published in 1966 and 1967, 'creative participation' and 'decision-making play'. ${ }^{18}$ The interdisciplinary and integrative character of cybernetics allowed a 'cybernetic vision in art', or 'esprit cybernétique', to extend beyond a mere set of technical procedures or devices to become a 'fundamental attitude toward events and human relationships. ${ }^{19}$ Cybernetics promised to be a lingua franca applicable across diverse cultural phenomena in addition to its original application in engineering, computing, and psychiatry. For Ascott, this spirit was only the most recent instance of a more general tendency in modern art to move from the production of objects to the elaboration of 'a field of behaviour', which in turn led a spectator to become a participant as he or she was drawn into a feedback loop. ${ }^{20}$ Entry into this field required 'decision-making play'. (Strangely, despite proclaiming himself to be 'the artist responsible for first introducing cybernetic theory into art education and for having disseminated the concept of a cybernetic vision in art', Ascott was not invited to contribute to Cybernetic Serendipity. In early October 1968 Ascott had provisionally agreed to participate in 100 Toys, although he then made no contribution to Play Orbit itself. ${ }^{21}$ )

Ascott was not alone in this view. Psychologist Michael Apter, writing in 1969, declared cybernetics to be 'a development in science which holds out the promise of taking art seriously', just as artistic activity also appeared to offer an opportunity to manage and model cybernetic apparatuses and complex systems. ${ }^{22}$ The rapprochement 
between art and cybernetics had come about not least because the latter was a means to describe process and transformation at precisely the time that art had become process-oriented and open to participation. For Reichardt, too, cybernetic devices would fully realize the potential of such developments as kinetic art, which, although promising much, too often had made the dynamic organization of the work inversely proportional to spectator involvement. 'It is with the advent of cybernetic machines', she declared in 1967, 'that the sort of dialogue between object and spectator that kinetic art so far tentatively proposes, can become a functioning reality.'23

More generally, cybernetics was of interest to artists, Apter suggested, because it offered a ground upon which science and art could meet and because 'in some obscure way [it] points to the world of the future'. ${ }^{24}$ Early in the conception of Cybernetic Serendipity, Reichardt stated that cybernetics would allow 'the industrial process [to be seen] in light of creative activity', and that by 'placing people, ideas, and things in what appears to be an out-of-context situation ... new possibilities will undoubtedly emerge. ${ }^{25}$ Apter praised Cybernetic Serendipity as 'a high point in the development of a self-consciously cybernetic art' and gave some indication of what these new possibilities would be. ${ }^{26}$ Especially important was the convergence evident between artistic process and the cybernetics of open, adaptable systems that included feedback and participation, and which led to 'the blurring of some of the traditional distinctions between the work of art and the system which creates the work of art, and between the work of art and the system which observes the work of art'. ${ }^{27}$

In many of her statements, Reichardt seems motivated by this same esprit. In her book The Computer in Art, published in 1971, Reichardt quotes approvingly from Apter's essay: 'Cybernetics, in its quest to understand complex human behaviour may be able to throw light in due course on that highly complex type of behaviour called "artistic" - a type of behaviour clearly involving control and communication. ${ }^{28}$ She notes, again following Apter, that the cybernetic notion of feedback, in particular, 'has entered the world of happenings as well as various environmental constructions, where audience participation and reaction can alter the appearance and even the content of the work in due course.29 (In fact, the 'world of happenings' had done a great deal to introduce cybernetic ideas into art practice in the late 1950s, to the point that the Black Box became what Judith Rodenbeck calls a 'contemporary imaginative motif' for the transition from form to process in post-war art in the US. This motif brought cybernetics together with proto-minimalist sculpture, avant-garde theatre, and a behaviourist approach that denied any significance to interiority in the production and interpretation of art. More on Black Boxes below. $)^{30}$ Indicating the broad application of cybernetics and continuity in her own interests, Reichardt notes that the subject of her book, 'computer-generated graphics as an art medium', cannot be understood without mention also of 'environmental art, cybernetic systems and audience participation'. Many of the works that result 'have no significant aesthetic value' but are 'do-it-yourself platform[s] [which have an] important sociological implication', because, again, they model complex social behaviour. ${ }^{31}$ Is this influence reciprocal? Might other exhibitions that organize complex social behaviour also be understood in view of cybernetics? Reichardt stated that Play Orbit's significance, too, was sociological more than aesthetic. Many of the toys required feedback and spectator participation and could be described as do-it-yourself platforms. It is reasonable to suppose that, bookended as it was by Cybernetic Serendipity and Reichardt's further reflections on computer-generated art, Play Orbit continues the cybernetic investigation of complex social behaviour, on this occasion in the domain of play. 
Yet Reichardt's doubt remains, which poses a problem of intention, of the purposefulness or 'forward-leaning look', to borrow Michael Baxandall's phrase, of an exhibition such as Play Orbit. ${ }^{32}$ Reichardt's intentions for Play Orbit were comparable to those for Cybernetic Serendipity. First, both proposed play participation as the ideal mode of visitor engagement; second, they sought to collapse professional distinctions between artists and non-artists and institutional distinctions between works of art and other artefacts; and third, they sought to present the exhibition as an arena in which art and science meet. Reichardt's own view was that an experimental work of art should be tested on the public 'in a scientific manner'. These intentions follow from Reichardt's personal interests and commitments as critic and curator as she responds to then current developments in artistic production and display. Where Reichardt casts doubt upon the connection between these two exhibitions we might attribute intention less to her as an individual curator and more to the exhibition in selective relation to its circumstances. These circumstances might be viewed as a brief to which an exhibition responds and against which it might be evaluated.

For both exhibitions, I would argue, intention was shaped by this cybernetic spirit. At stake in this reconstruction of the intention of Play Orbit is, therefore, an understanding of the impact of cybernetics upon artistic production and display during this period. Ordinarily, the narrative of post-war British culture has promoted play and participation as a humanist corrective to a technocratic and automated society controlled by cybernetic means. Play Orbit, in particular, collapses, or at least complicates, this opposition by expanding cybernetics to the social domain. It thereby aligns with what Bruce Clarke has called a 'systems counterculture', active from the late 1960s through the 1970s, especially in the US, which sought to investigate cybernetic ideas and practices beyond their technocratic application and to detoxify "the notion of "system" of its military, industrial, and corporate connotations of command and control and [redeploy] it in the pursuit of holistic ideals and ecological values'. ${ }^{33}$

\section{Play Participation}

The first element of the brief was that an exhibition facilitates participation. A toy offers an ideal means to achieve this because of the obvious fact that it requires play. A review of Play Orbit by Alastair Best, published in the journal Design in 1969, articulates this clearly. Best contends that what mattered most was 'the attitude to play rather than the plaything itself'. The participatory works in B and C sections were most successful in this regard: 'Some of the best toys are purely constructional (the participation element) and need no accompanying treatise from their creators. ${ }^{34}$ The 'participation element' promised a more direct engagement with materials, structures, and processes, without the need for institutional mediation. Pathé footage of the exhibition shows children of various ages engaging with toys often without adult supervision or, it appears, without prior explanation. ${ }^{35}$ In B Section, toys such as Islwyn Watkins' Hinged Toy Number 1 (plate 4), a serpentine articulation of twenty-six painted five-centimetre wooden cubes, Robert Johnson's Multicube, a set of patterned twenty-three-centimetre cubes which served as an 'image kit', Billie Old's Pentominoes, a set of wooden building blocks, and Richard Horden's Multiple Construction, consisting of 200 identical units that could tessellate in various ways, all appear to have been 'purely constructional', and thereby to have successfully prompted the attitude to play. The footage also shows C Section, where by far the most popular among the toys and environments 


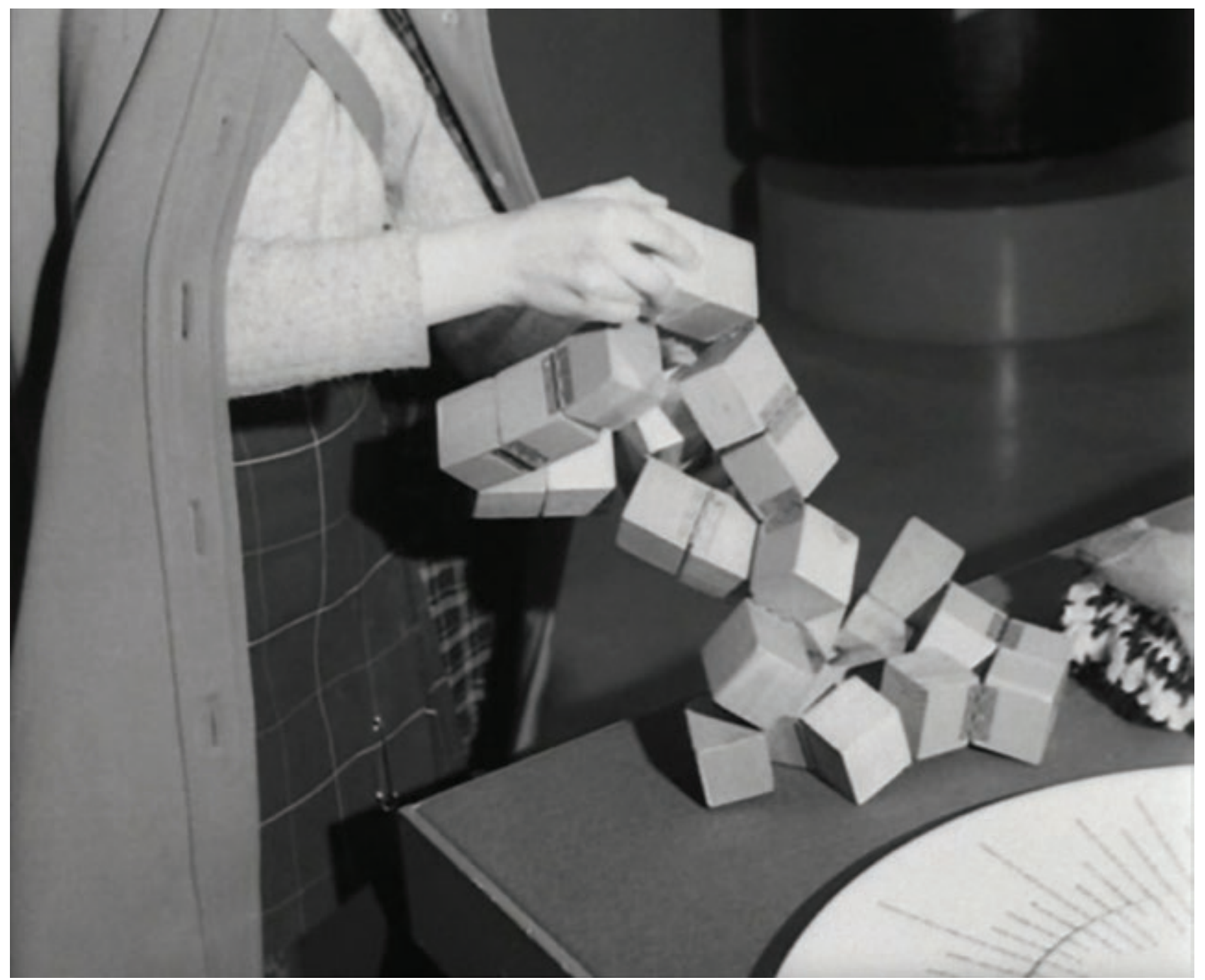

4 Film still from footage of Play Orbit exhibition, showing children playing with Islwyn Watkins, Hinged Toy Number I, 1969. Twenty-six painted and varnished hinged wooden blocks, each $5 \times 5 \times 5$ cm. Pathé 3328.05. appears to have been Dutton's Elasticlimb and the Rotating Land/Water Toy and EccentricMovement Activity Toy supplied by Foundation Year students at Guildford School of Art (plate 5). These are toys that require physical involvement, often of the entire body, and some degree of collaboration between players. Writing of the toys from Guildford, Ian Hunter, Head of the Department of Foundation Studies at the School, notes that 'Particular emphasis was placed upon the need to engage the child's, or parent's, participation in the use of the toy in a physical way. The scale of the toys is a direct result of this requirement. ${ }^{36}$ Dutton, in a more enigmatic statement, alludes to the mastery participants might gain: 'A toy is a situation which enables the participator/operator to grasp hold of a mental/physical state, which makes him larger than life. ${ }^{37}$

A number of exhibitions at the time promoted participation, if not play itself. The title of Best's review, 'When Attitudes Become Toys' (which also prompts the title for this essay), mimics that of the exhibition Live In Your Head: When Attitudes Become Form, curated by Harald Szeemann and shown at the Kunsthalle Bern from 22 March to 27 April 1969. Live In Your Head assembled works that exemplified postformalist and conceptualist tendencies towards serial or modular construction, whose makers had abandoned objects in favour of open processes. In his introduction to the exhibition catalogue, Szeemann wrote that 'The major characteristic of today's art 
5 Guildford School of Art (Calvin Lucas, Philip Gregory, Kenneth Ansell), Rotating Land/Water Toy, 1969. Painted plywood, 127

$\times 76 \mathrm{~cm}$. Guildford School of Art (Raymond Duns, Janine Cairns, Tom Saddington), Eccentric-Movement Activity Toy, 1969. Blockboard and PVC with polyurethane foam, icosahedron with 61 cm edge. Guildford School of Art (Joyce Blackley), Circular Capsule, 1969. Blockboard and polythene, $91 \mathrm{~cm}$ diameter. Jasia Reichardt and Peter Jones, Play Orbit, exhibition catalogue, Studio International, special issue, 1969/70, 156.

\section{Guildford School of Art}

Rotating land/water toy Calvin Lucas. Philip Gregory, and Kenneth Ansell

Eccentric-movement activity toy Raymond Duns, Janine Cairms, and Tom Saddington

\section{Circular capsule}

Joyce Blachley

In the pest individual students at Guildford have ctrosen to design and develop sors This is the first time, however, that specific projacts strictly concewned whe tovs and partcingtery soujphas hwe been intro duced is part of the founderen coure. The studerts were aited to cortider one of The studinits were asied to conchier one of

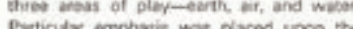
Proticus amphatis was pracod laon the asod wo engags the childs. of porter's? partcipaton in the vas of the bor in ptricial way. The seate of the tors a

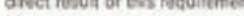

ldeas were tholougridy walyated for techinical nebity and satabity beloce maquectes wale producad Malarials uned have varied with the function of each boy and covid be in at caser improved log fibtedats icosahedron insted of wood construction)

Though childen have played with the tor during the programme. time has not vet allowed at thensugh ne-avaluaton of the works produced

The eftect of the proipet upse the students has been to derrand rescarch mo huma behmour, end a stringent consideration of the muterial reouitements consistent imith

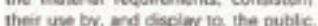
lan Hunter

Head of Desarment of Foundesion Studes
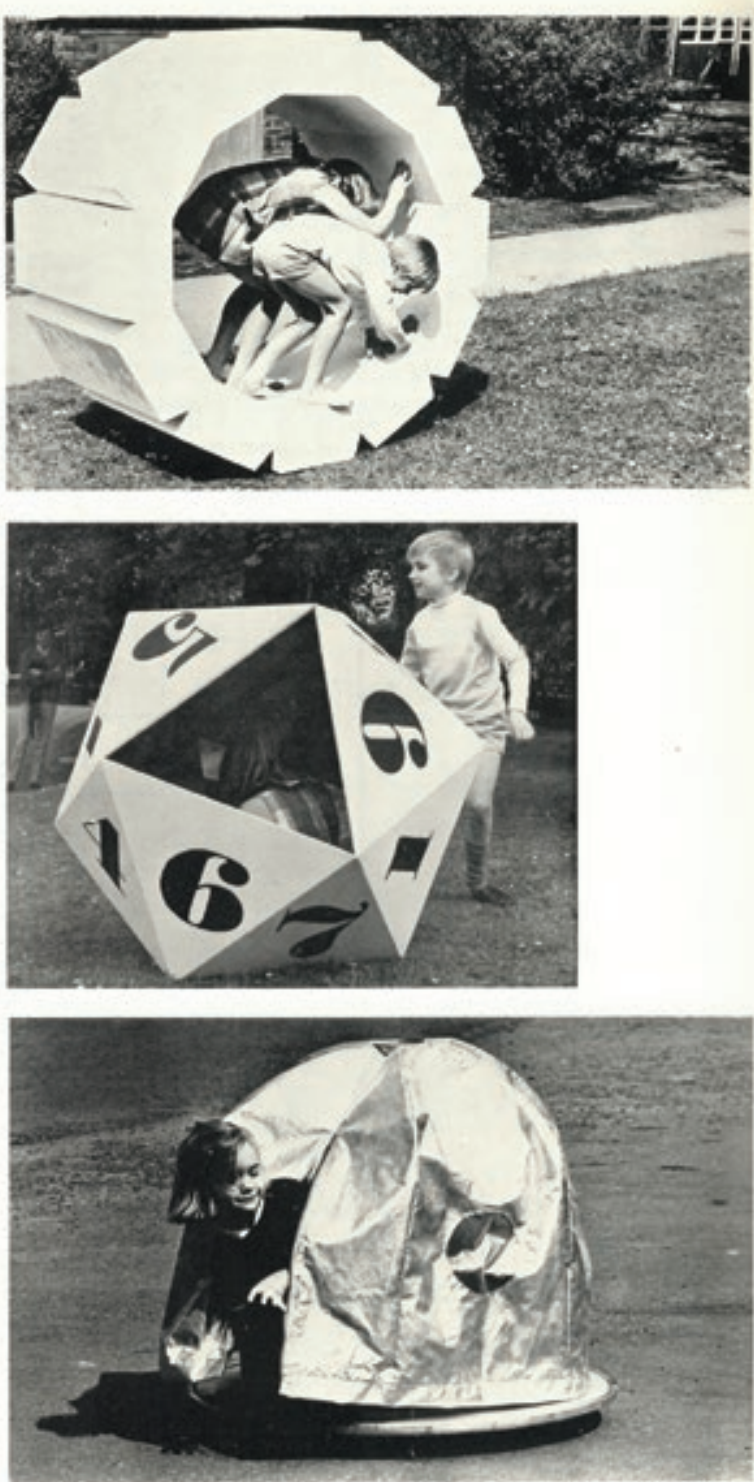

is no longer the articulation of space but of human activity [die Tätigkeit des Menschen], with the artist's activity being the principal theme and meaning. ${ }^{38}$ Live In Your Head has now become canonized as, in the words of Germano Celant, who restaged the exhibition in the Ca' Corner della Regina, Venice, from June to November 2013, 'an emblematic and mythical manifestation of a visual and plastic research that had developed a taste for breaking down the separation between art and life, bringing into its territory attitudes and materials that were then considered to lie outside its purview'. ${ }^{39}$ Following Live In Your Head, Brandon Taylor writes, a number of alternatives to formalist modernism reconfigured the relationship between the art object, its setting, and its audience. These included:

'inexpensive' attitudes to the gallery as a social space; a marked drop in the importance of discrimination, fine feeling, empathy, or 'good taste'; the generation and deployment of non-aristocratic social networks for artists, 
gossip and repute; radical attitudes to mental or physical participation in the work; the possibility of linkages with wider social and political ideals; and a new appraisal of what now became widely known as the 'ontology' of the work. ... 'Participation' was perhaps the key term. ${ }^{40}$

Although these alternatives began to emerge prior to Live In Your Head, the exhibition certainly confirmed their legitimacy for large-scale exhibitions at public institutions. Play Orbit, too, developed these alternatives. Play participation required evaluative criteria quite distinct from those of 'good taste' or fine feeling and connected with social networks in which play was idealized. Again, the ontology of the work is at issue, especially in view of participation. In this latter regard, Play Orbit goes further than Live In Your Head, where the attitudes in question remained principally those attributable to the artists involved. With Play Orbit, an artist's activity enjoyed much less privilege, making its toys and playables more prosaic, perhaps, but no less significant as manifestations of visual and plastic research.

Reichardt was dissatisfied with works of art that promoted a participatory mode of engagement but which failed to achieve it. In March 1968, again writing in Studio International, Reichardt makes first mention of a proposed exhibition, 100 Toys, in her essay 'Non-games'. In response to the 'information explosion' brought about by an increase in communications media and computing, Reichardt notes that a number of artists have become more esoteric in order to retain the singular value of their work. She then discusses a number of examples, especially books and games with which 'one cannot do anything'. ${ }^{41}$ Reichardt uses the example of fluxus artist George Brecht's Deck of 1966, a pack of fifty-two playing cards without suits or numbers, each card of which shows a unique pattern, drawing, and diagram. Deck invites a player to make his or her own rules. However, Reichardt observes, 'The cards are objects which invariably are looked at and then put down' (111). Such a game demonstrates an 'attitude' which is private and nihilistic. Reichardt concludes by stating that such esoteric works and 'the phenomenon of easily accessible information' are 'irrevocably interdependent', but that the former need not result from the latter (111). She then introduces the exhibition 100 Toys, which implicitly responds to these non-games through an open invitation to exhibit and through play participation. The test of such an exhibition would be to produce successful toys, which, in contrast to Brecht's card pack, could not be put down.

If participation is viewed as a problem to be resolved, and therefore as part of the brief of a progressive exhibition such as Play Orbit, there appears no better response than to encourage play. To do so, however, requires an artist to abandon some of his or her privileges, whether that be an activity or an attitude. This, at least, was the view of Reichardt. As a consequence, the second element of the brief was that an exhibition collapse professional distinctions between artists and non-artists and institutional distinctions between works of art and other artefacts. The introduction of playability as a principal criterion of success, which characterizes both Cybernetic Serendipity and Play Orbit, responds to this. It was, for Reichardt, an attempt to democratize, or at least popularize, the public exhibition of 'creative endeavours'.

\section{To Democratize 'Creative Endeavours'}

In June 1968, prior to both of these exhibitions, Reichardt lamented the fact that the conventional uselessness of art meant that: 'Many creative endeavours today are directed solely towards a tiny section of society - one could make it narrower still by describing it as friends and collaborators. ${ }^{42}$ To counter this situation, 
Reichardt suggests that an experimental work of art should be tested on the public 'in a scientific manner' (290) and refers to Simon Nicholson's Design 12 course, established in 1966 at the College of Environmental Design at the University of California (Berkeley), as an exemplar of this approach. The course demanded every student product to be 'self-instructional' and to be tested on an audience of children. The products, wrote Reichardt, 'were to be structures for use by children who, in the course of coming into contact or playing with them, would learn something in the process' (290-91). The games and play objects developed by students on this course, Nicholson argued, were to simulate 'the invention, construction, and testing of a building' and so emphasized participation, cooperation and assembly. ${ }^{43}$ Reichardt worried that if Nicholson's approach was instituted with 100 Toys, 'the number of entries would prove rather small ... Even without thinking about a toy that is self-instructional one wonders (and I have been wondering for some time) how many of the toys one will actually be able to play with and how many will

\section{Simon Nicholson \\ Magic blower \\ The Magie blower owes its name to the lase Sir Hertbert Read, who called its amaller pro- totype 'Magoc wands': my interest an seif: instructional stuxtures rew/ted from my chence to intien a new couse concerwing ituract games at the University of Callernia If Berkeley: the functions of the biower ars fundrrenial-sol would the insteed bo men. tion the characteristics of the magc blope that relata to venal art in caneral for I beiteo that these cheracterintics well tranderm of es we known today: \\ 1. The meoc binwer does net aepend teiety

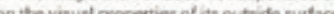 on the visuel propertios of hits cutside syiface. thases not corvest solety of \\ solety of solid com: \\ porients. parts \\ It allows for meximum imolvement by participanta, including more than one kind of \\ 6 Both the magic blower and participant move and interact with each other 6 it allows for both quantive and qualit: the experiments \\ 7 it moess the most important functional no gurement of all : the clament of the unes. \\ 8 The magic biower a fun Whiy can't more sculptuies be fun?}

\section{Billie Old}

\section{Pentominoes}

Toys are colects of which the purpose is 10 peovoke shyaisal and/ee mental inohroner end giving enicoment in return.

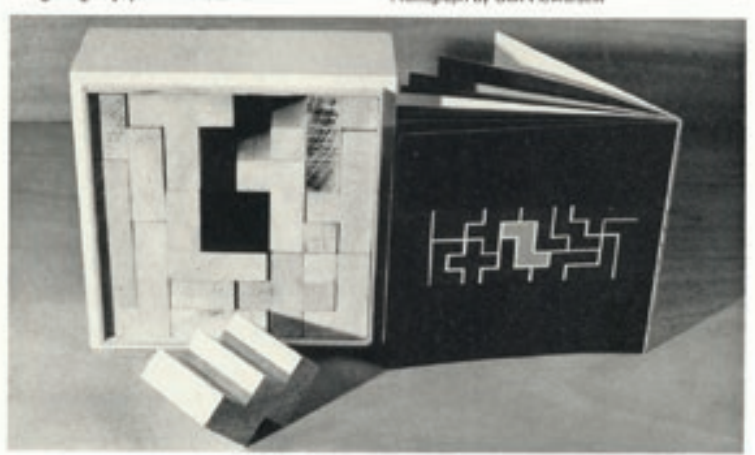

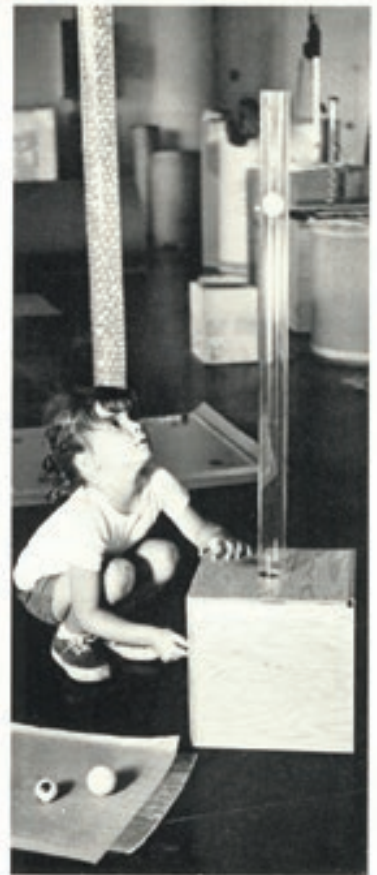

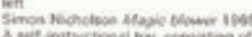

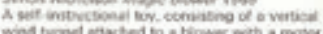
contol the ntensty of wint. The wrod hemel is.

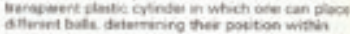

\section{Barbara de Orfé} Space tree

Basically, I foel a toy is amy obiect, however sumple of complex. which. Hrough the magnative play uses to which it is put by its maker of owrow. tatisfies ionse deep. nener need. Thus, I foel age is no barrier to the mivaduafs need for auch objects. altheugh the noods themselves and concoquentry the chosen objects, will change as one grow and devolops Prenonely. I whe the toy to be a 'fun abject, not tealistic, end capeble of being aliered is form by whoever happens to be using it. Hence my 'Space tree' is meds from very int-bec-like' parts which imegina ticn can change at will mo toots gras. tranches budi losves and so on it can bo taken to pieces and meconstructed at ene

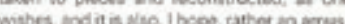
ingobiect in itsel!

Hater de ons Sneve ren ives?

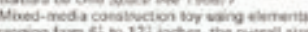
$5060 \times 48 \times 48$ indea ton inote of

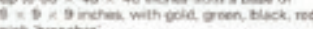

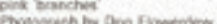

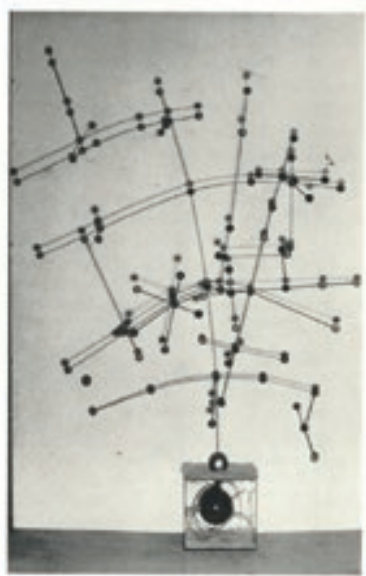


actually work' (291).

Her concern was largely misplaced. Many of Play Orbit's toys prompted play, including Nicholson's own contribution, a 'self-instructional sculpture' called Magic Blower (plate 6). Named after a smaller prototype that Herbert Read called Magic Wands, Magic Blower consisted of a long transparent cylinder linked to a switch-operated fan. Various materials could be placed in the cylinder and blown along it. Participants had to 'invent some of its parts' and could interact with it fully in fun and unexpected ways. ${ }^{44}$ It was a 'high-interaction environment', Nicholson wrote, 'with many loose parts' or variables with which to play. His 'theory of loose parts', developed after Play Orbit in 1971, stated simply that 'In any environment, both the degree of inventiveness and creativity, and the possibility of discovery, are directly proportional to the number and kind of variables in it. ${ }^{45}$ Reflecting upon his Magic Blower, he asks, 'How much of a sculpture does the artist invent, and how much does the public invent?' In answer to his question, Nicholson recounts that 'Joey Schlenhoff, a young boy who came to Play Orbit, went back home and invented his own', although just what he invented remains a mystery. ${ }^{46}$ What is clear is that according to the criterion of playability Magic Blower was demonstrably a success. Art and science 'exploratoria' (and with this term, Nicholson gives a nod to Frank Oppenheimer's playful science museum, the Exploratorium opened in San Francisco in 1969) such as Play Orbit or the Robert Morris retrospective at the Tate in 1971 are initial responses to the scant availability of loose parts in most environments, whether architectural, educational, cultural, or otherwise, Nicholson claims. ${ }^{47}$ Such exhibitions might assist a new generation to 'invent new systems with the parts', all of which suggests that, for Nicholson, and for his supporter, Reichardt, play participation was a means of systems building and testing made available to a broad audience. ${ }^{48}$

This was evident with the rather conventional group exhibition, 100 Toys, with which Reichardt began. In autumn 1968, invitations were sent to a hundred prominent artists resident in Britain or British artists living abroad to submit any toylike or game-like works of art they might have made but had not exhibited. Despite this conventional selection process, at this early stage the exhibition itself was already anticipated to be something of a departure from the norm. The introduction of toys into the exhibition space required a transformation of its architecture, at least. In a letter of 26 February 1968 to Francis Hawcroft, Keeper of Whitworth Art Gallery, Manchester, ICA Director Michael Kustow suggested that 100 Toys might travel north after its run in London. The toys, he wrote, were to be displayed in 'an environment something like a climbing frame, involving swings, see-saws, curly staircases, and play areas where we asked the Art Colleges to create giant interpretations of traditional games'. He then enthused: 'I think it is going to be one [of] our most exciting exhibitions since Cybernetic Serendipity. ${ }^{49}$

Kustow was right to anticipate that Play Orbit would be as exciting, and certainly as popular as Cybernetic Serendipity. This was largely because both slackened, if not abandoned professional and disciplinary boundaries between artists and public. With Cybernetic Serendipity, there was no indication given of the affiliation or profession of the makers and authors of the different works, in order not to give further support to what Reichardt called 'categorical assumptions about our various talents, functions, and possibilities [that in 1968] are less accurate than ever. ${ }^{50}$ After the selection process for 100 Toys had been abandoned, the open invitation for contributions to Play Orbit showed a similar disregard for conventional methods of artistic discrimination and assessment. More so than any other exhibition of that moment, Play Orbit overcame the prevailing artistic hierarchies of materials, activities, and attitudes in 
both the production and the display of works.

What, in the planning of 100 Toys, led Reichardt to change the exhibition from invitation to open submission? Reichardt does not disclose why this occurred. There may have been practical reasons. Certainly, it appears to have been difficult to find one hundred artists willing or able to contribute toys. By early October 1968, less than half of those invited had provisionally agreed to take part. ${ }^{51}$ Judging by Reichardt's commitments, as outlined above, perhaps it was also awareness both of the democratizing consequences of an exhibition of toys, with which visitors would have to play, after all, and that the inclusion of contributions from art students would open the door to counter-cultural contestations to traditional methods of artistic production and display. An open submission would be more in keeping with the egalitarian demands of these contestations.

This is the suggestion of Michael Punt, a contributor to Play Orbit, who notes that currents in the art colleges and schools of the time carried over into the exhibition, where many contributors refused both modernist essentialism and the patriarchy of canonical continuity. Play participation served as the ideal mode for this 'counter-attack':

[The artists'] provisional, playful and witty responses to the absolutist assertions and mechanistic models of causality saw the recovery of longforgotten art and ideas from the fringes. By situating this counter-attack in the discourses of play (with all its dilettante and ephemeral connotations) they avoided the criticism of merely displacing one order for another. ${ }^{52}$

Play's provisional and contingent orders opposed the procedural fixity and specializations of curricula derived from modernist essentialisms. There were Play Orbit contributions from both Hornsey College of Art and Guildford School of Art where, in 1968, well-publicized protests had taken place over curricula and amenities. However, Punt is too quick to present play as disorder and disruption, rather than simply another mode of ordered activity, albeit often more open and flexible than previous modes of art education. In fact, reorganization, not disorganization, was at stake in many of the art school protests. At Hornsey, the principal demand was for a 'network system', based upon an open and nonspecialized pedagogy, to replace a 'linear system' that was oppressive, overspecialized and out of date. The network system would allow skills and disciplines to correlate according to the aims of particular student projects, would emphasize process and the unification of art and design, and would produce a 'flexible training in generalised creative design, adaptable to changing circumstances. ${ }^{53}$ Most significant here is that the students of Hornsey, aside from their occasional rhetoric of 'smash the system', sought to replace one systemic order with another, more fluid, adaptable and open to play.

Many alternative arts practices used play as an egalitarian and participatory means to organize extra-institutional and leisure-based modes of sociability.

7 Flyer for Yoko Ono, unnamed event, Sunday 4 June 1967 on Parliament Hill, London. Photo: Courtesy of Yoko Ono/Galerie Lelong. Jasia Reichardt, 'Art is Big, Round, and Good', Studio International, 174: 892, September 1967.
Reichardt was aware of this. In 1967 she wrote how leisure and entertainment activities were increasingly used by the artistic 'underground' as a means to develop forms of 'total art'. She used the example of Fun Palace, a 'socially interactive machine' proposed by Joan Littlewood, Gordon Pask, and Cedric Price in 1962, and which had its own Cybernetics Subcommittee headed by Pask..$^{54}$ The architecture of the Palace aimed to be 'informal, flexible, unenclosed, and impermanent', and would allow both optimum entertainment and the various needs of its inhabitants to be satisfied 


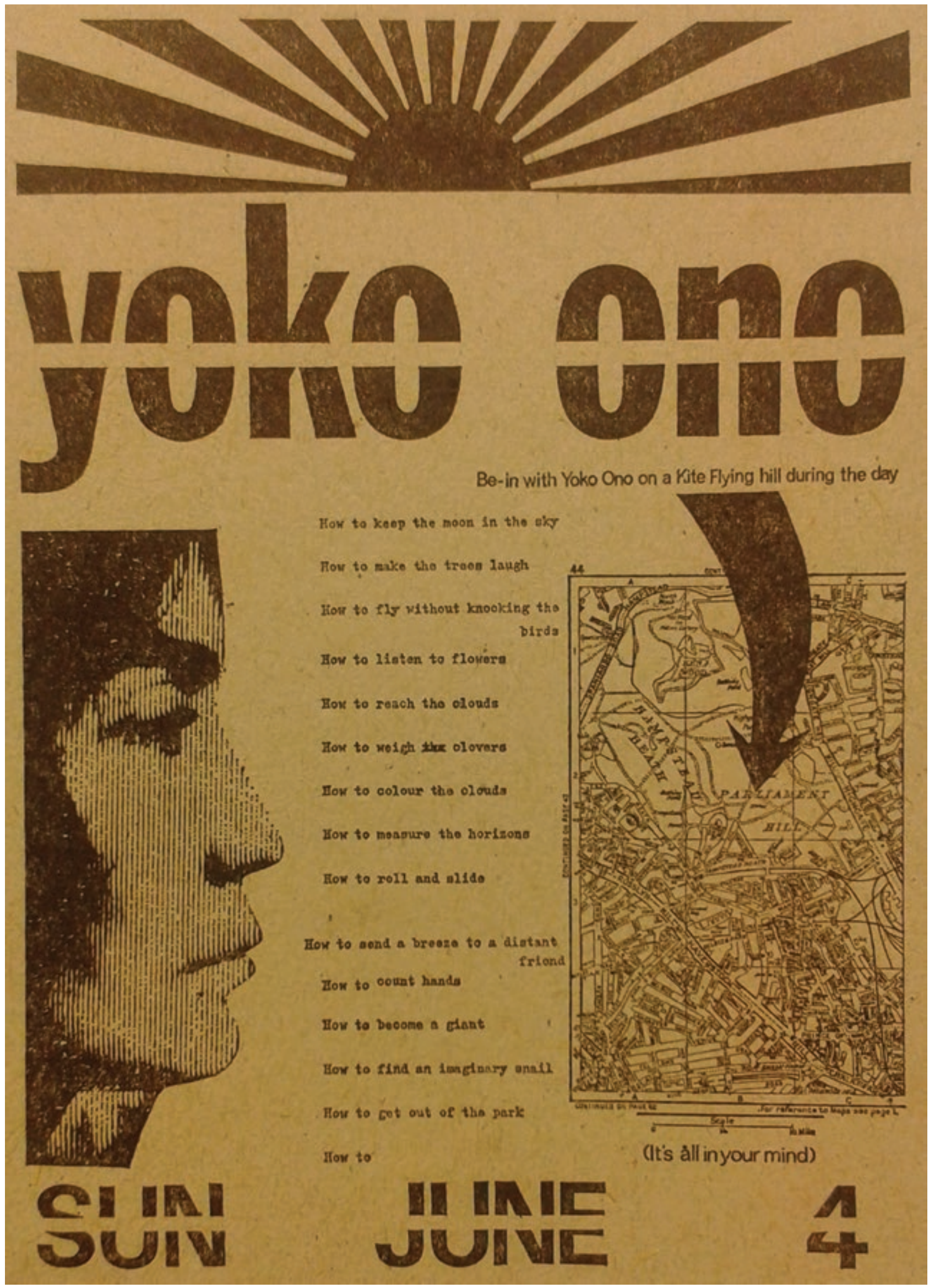


as and when they arose. ${ }^{55}$ Reichardt described it as 'a kind of network in which people's free time would be manipulated for their own good and delight ${ }^{56}$ Despite its promise of a cybernetically controlled, adaptive architecture for the purposes of optimizing leisure time, Reichardt noted that Fun Palace was rejected in discussion with students of Cardiff College of Art because it appeared too hierarchical and too reminiscent of a holiday camp.

Yet still, Fun Palace foresaw 'the merging of the fun fair/amusement complex with the aspirations towards ideology/avant-garde which activities of young people manifest today' ${ }^{57}$ It promised a 'combination of creativity, amusement and freedom' which, for Reichardt, was more fully realized in 'be-ins', such as that organized by Yoko Ono on Sunday 4 June 1967 on Parliament Hill, an area of parkland in the south-east corner of Hampstead Heath, London (plate 7). Ono's 'be-in' consisted of kite-flying, dancing, music, and knitting, and lasted for five hours. Reichardt was most impressed by the organization of the event. 'Be-ins are above all democratic', she wrote, 'they may look like a substitute for political commitment or some more demanding occupation with which young people could occupy themselves, but they are organic, self-regulating and self-supporting.' As such, they connect to 'the art of the future. ${ }^{58}$

Although at this stage (September 1967) Reichardt does not propose an exhibition of toys at the ICA, she demonstrates a clear interest in the democratic possibilities of sociability through play. These possibilities were already explored through a counterculture and underground that privileged creativity, amusement and freedom. Cybernetics itself was enlisted to this end. The Fun Palace, in its attempt to transform 'unmodified people' into 'modified people' through networked entertainments, might have discouraged some, but the difference between this and the organic and self-regulating be-ins is one of degree, not of kind. ${ }^{59}$ Similarly, if play was a 'counterattack', as Punt maintains, it was precisely because it offered to displace one order for another. The attempt to collapse the professional and institutional distinctions that make the public arts institution exclusive and remote is a response to this problem of organization, of how different types of sociability, including leisure activities, might be organized. In his essay 'Systems Esthetics', published in September 1968, critic and curator Jack Burnham states that 'the priorities of the present age revolve around the problems of organization'. To address these problems, Burnham recommends a 'systems viewpoint' that focuses 'on the creation of stable, on-going relationships between organic and non-organic systems, be they neighborhoods, industrial complexes, farms, transportation centers, recreation centers, or any of the other matrixes of human activity'. ${ }^{60}$ Although her own 'systems viewpoint' is not explicit at this time, and will become so only in the planning of Cybernetic Serendipity, a year prior to Burnham's essay Reichardt identifies play, and its extension into leisure activities, as just such an organizational problem.

\section{An Adult Play Centre}

The ICA identified itself from its beginning as an institution that would foster play. In 1947, co-founder Herbert Read proposed the ICA as an 'adult play centre, a workshop where work is a joy, a source of vitality and a daring experiment'. ${ }^{61}$ The following year, Read declared the Institute's ambition 'not only to entertain and educate the general public' but to bring the public 'into intimate contact with the artists, so that a new creative effort may spring from a new sense of communion or mutual understanding.'. ${ }^{2}$ Play was central to this creative effort because, as Read wrote in Education Through Art, published in 1943, it was a plastic, largely non- 
visual mode of expression and a rudimentary 'form of art'. 'All forms of play', he wrote, 'are so many kinaesthetic attempts at [the] integration' of fears, wishes, and fantasies. ${ }^{63}$ David Thistlewood writes that, from its inception, the ICA's two most important educational issues were 'the analogous relationship between modern art and modern science and the principle of adopting "primitive" percipience toward visual and plastic creativity. ${ }^{64}$ It is clear that, for Read, play exemplified such percipience. Many of the contributors to Play Orbit appeared to support this view. Contributors' answers to the question 'What is a Toy?' frequently include claims for play as a rudimentary mode of understanding, of how, for example, it 'excites the spectator's interest and curiosity in tactile and visual situations' or functions as 'a medium for experiencing touch and control'. ${ }^{65}$ The curatorial assumption of Play Orbit, as well as the opinions of many of its contributors, accords with Read's claim that play offers a rudimentary form of plastic expression, less specialist and more participatory than the domain of art.

By 1964, in the short essay 'Atrophied Muscles and Empty Art', Read presented play as a corrective to what a New Statesman editorial of the previous year had called 'The Terrible Challenge of Leisure'. ${ }^{66}$ Read deplored the predominance of spectacular entertainments that encouraged only passive enjoyment and were an unsatisfactory response to the problem of how to fill time in a society of increasing affluence and automation. Yet entertainment might become play when it is 'active, participated in, [and] practised'. ${ }^{67}$ In Read's view, an art that takes play as its mode of production and exposition might solve the problem of leisure and engage the 'new creative effort' that he had called for sixteen years previously.

Reichardt's interest in the organization of leisure has been noted above. Play Orbit itself shows sympathy with Read's concerns in so far as the catalogue republishes the first and final chapters from Sebastian de Grazia's Of Time, Work and Leisure, published in 1962. De Grazia argued for leisure to be realigned with contemplation and learning rather than with recreation and entertainment. Leisure, now defined in terms of motivation rather than simply free time, should be expanded beyond a leisure class that depended upon workers who were then offered compensational amusements and diversions. ${ }^{68}$ Such arguments about the character and proper use of leisure became especially urgent to an increasingly automated post-war society. Consequently, as Play Orbit contributor John Berry proclaims, the future role of the artist should be one which supplies 'some of the leisure activities of a nearly workless society brought about by the development of automation and robotics'. ${ }^{69}$ With Cybernetic Serendipity and then Play Orbit, the self-proclaimed 'adult play centre' of the ICA staked a claim as something of an experiment in 'motivated' leisure activity.

\section{An Arena for Art and Science}

The first 'educational issue' for the ICA, as noted above by Thistlewood, was the relation between art and science. In his intellectual biography of Read, Thistlewood stated that the ICA was conceived as an anarchistic social experiment as much as an exhibition space which sought in art 'an expression of the scientific Zeitgeist, and to find respectable common principles - [such as] a theory of organic formation in physical science, a science of mind, and an explanation of creativity'. ${ }^{70}$ Read's collaboration with physicist Lancelot Whyte, which led to the exhibition Growth and Form in 1951, exemplified this ambition, as, too, did the appointment in March 1949 of art historian Josef Paul Hodin as Director of Studies and librarian for the ICA, asked to study the influence of scientific thought upon developments in contemporary art and even to advocate the scientific basis of contemporary art. In 1969, polymath and 
theatre director Jonathan Miller was elected to the ICA council and reiterated this ambition with his promise to 'bring the arts and sciences into one arena. ${ }^{71}$ Clearly, Cybernetic Serendipity was such an arena, as it provided a situation for viewers to reevaluate preconceptions about professional and disciplinary distinctions and about the broader social import of cybernetic technologies. ${ }^{72}$ It is less obvious whether or not Play Orbit was too. On closer inspection, however, Reichardt's views on the playability and testability of Play Orbit's contents, noted above, appear to betray a cybernetic approach based upon feedback and decision-making play as a means to engage with complex systems and Black Boxes.

As Reichardt's views on participation and testability show, this approach entailed a distinct understanding of artistic production. A decade earlier, in a lecture given at the ICA in April 1960, titled 'Art and Communication Theory', British psychiatrist and cybernetician W. Ross Ashby had already discussed this. One advantage of cybernetics, Ashby claimed, is that it concerns only what is demonstrable and therefore has 'exactly nothing to say on this subject of the internal personally felt aspect of things' ${ }^{73}$ In this view, artistic activity is meaningful only according to the information-theoretical distinction between what was selected and what could have been but was not. As a result, and most controversially in Ashby's view, cybernetics describes such activity in a way that avoids the dichotomy of 'soullessly mechanical' or divinely inspired. Instead, it is based upon 'appropriate selection', which involves a great deal of 'drudgery' and failed tests. 'The person that produces some almost magical artistic creation', Ashby states, 'is not doing it in an actual magic way, he [sic] is following really a perfectly straightforward way that is essentially natural.' This natural process is simply one of testing out what can be done and of linking cause to effect toward a particular goal. It is therefore possible, Ashby concludes, that a computer, 'the completely plastic machine', would be capable of producing art.

In all but name, this is the approach advocated by Reichardt, most concisely stated in her essay 'Art and Usefulness' of June 1968:

Art is an act of transformation which may sometimes appear miraculous but which does not depend on miracles. When firmly based, it is likely to produce good test results and then it may be quite safe to leave the usual accompaniment of metaphysical explanations alone. ${ }^{74}$

Play participation, too, had no need of metaphysical explanations. Toys could be tested. Their playability, or lack thereof, could be demonstrated. Yet still, play, like art, might be an 'act of transformation' that emerges at a human/object or human/ machine interface. The egalitarian ambition behind the introduction of playability as the primary criterion for evaluation of Play Orbit's toys also brought those toys under a cybernetic description.

To place toys and play participation under a cybernetic description does not mean simply that players become subject to technocratic control, as Usselmann suggests with regard to Cybernetic Serendipity. ${ }^{75}$ Instead, Play Orbit might display the 'progressive posthumanism' that Fernandez claims for Cybernetic Serendipity. First formulated by Katherine Hayles in How We Became Posthuman of 1999, this version of posthumanism, rather than subordinate humans to technocratic control, emphasizes instead the necessity of embodied and contingent relations between humans and other agents, which latter might include machines but also artefacts, assemblages, puzzles, and so on. In this view, subjectivity emerges from such relations and cannot be separated from them. As Hayles defines it, 'In 
8 Film still from footage of Play Orbit exhibition, showing children playing with Alun and Elizabeth Evans, Structube, 1969. Assembly kit of treated cardboard tubing and wood, each unit diameter of $8 \mathrm{~cm}$ and varying lengths from 15 to $124 \mathrm{~cm}$. Pathé 3328.05 . the posthuman, there are no essential differences between bodily existence and computer simulation, cybernetic mechanism and biological organism, robot teleology and human goals. ${ }^{76}$ The posthuman player is not therefore unfree. Rather, the prefix 'post' identifies the limitations of the model of the liberal human subject at liberty to assert her will through her own ludic projects. If one adopts the posthumanist view of a player, however, 'there is no a priori way to identify a self-will that can be clearly distinguished from an otherwill', Hayles writes, which might be other players, of course, but also the rules, constraints, and materials that are constitutive of play. ${ }^{77}$ Cybernetic Serendipity was progressively posthuman because its demands for participation and interaction took subjectivity to be 'emergent and contingent', arrived at and tested out in play. ${ }^{78}$ Play Orbit was no different in this regard, as through its games, puzzles, and playables there emerged the subjectivities and complex social behaviours that had featured prominently in Cybernetic Serendipity.

\section{Again, What is a Toy?}

To summarize the above, Play Orbit's introduction of play participation into the space of art exhibition correlated to a change in the ontology of the works available to the public, a change in what type of thing the work of art was or could be and what

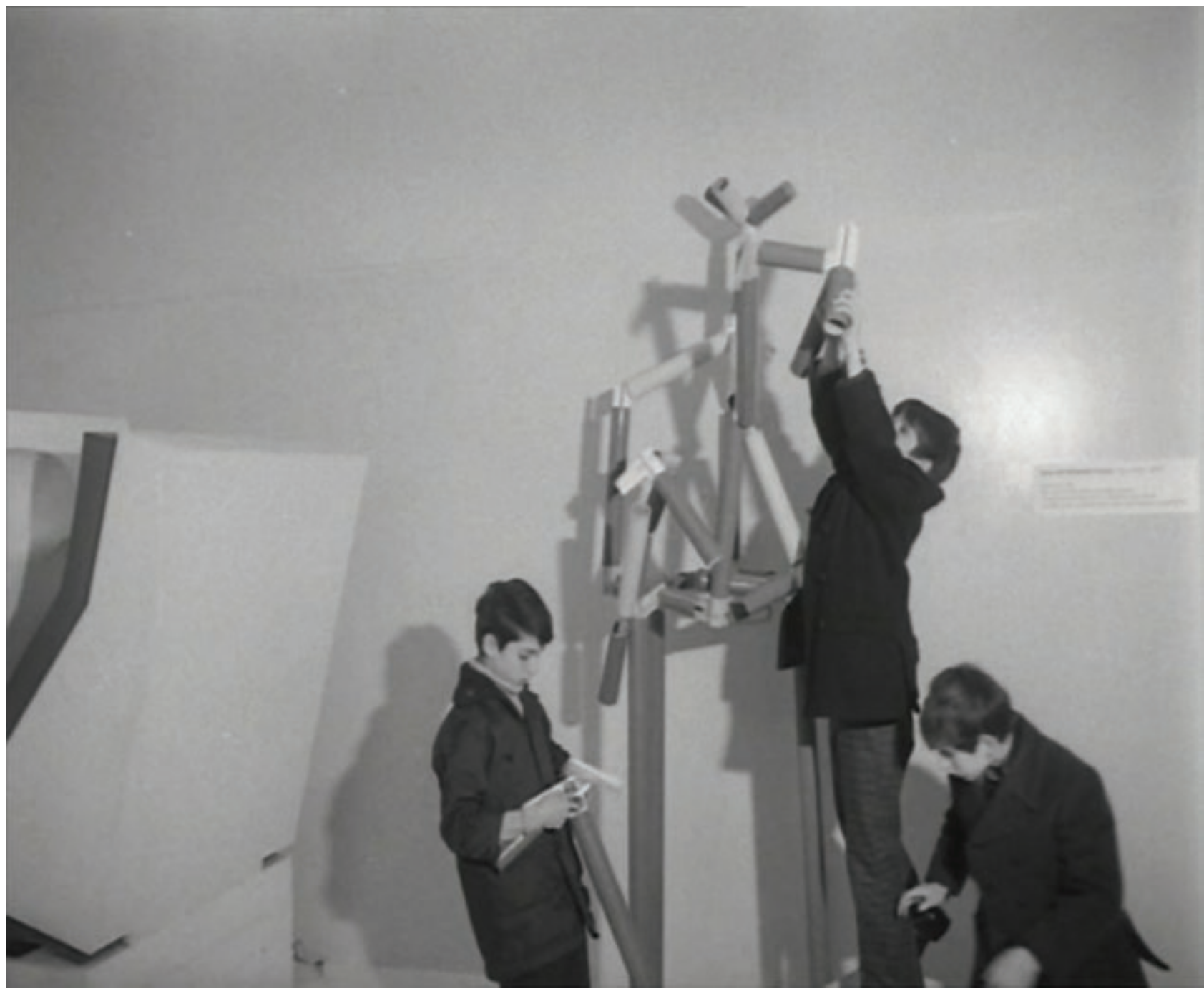


manner of engagement it required as a result. This ontology privileged performance over representation. In most cases, a player was to learn what a toy did, rather than, say, what it stood for. Many of Play Orbit's toys consisted of 'loose parts', or variables with which to play, and they were to be judged primarily according to the criterion of playability. Such a toy was cybernetic and would assist a new generation in systems building and testing.

This cybernetic ontology of toys can be developed further by again posing Reichardt's question to Play Orbit's contributors, 'What is a toy?' As discussed above, a toy necessarily consists of loose parts. Nicholson's Magic Blower clearly shows this, as do most of the constructional toys in the exhibition. For example, Alun and Elizabeth Evans's Structube, a kit of eight-centimetre cardboard tubing and wooden hinges, could be assembled to make 'a great variety of structures, including a rocket, a tent'. ${ }^{79}$ The Pathé footage shows three boys building an improvised assembly (plate 8). In such an instance, a toy, rather than a dumb apparatus discrete from participants, appears to be the result of co-construction.

Cybernetician Heinz von Foerster, whose work on cognition was central to developments in what became known as second-order cybernetics, described objects not as material entities but as 'tokens' for stable behaviour in a complex system. The stability of an object was due to the recursive application of observations to their own results. To clarify how this is done, in her intellectual biography of von Foerster Lynn Segal gives the example of a child playing with a ball. She writes, 'After sufficient interaction, [the child] begins to experience the ball as an invariant. His recursive behaviour, operating on the result of his previous operations, reaches stability. ${ }^{80}$ This is how objects must be understood, von Foerster claims, if observers are included in what they observe or the observer and the object, the plaything, belong to the same system. ${ }^{81}$ In play participation, then, a toy is, for its players, a recurrent selection and a constraint that objects to and restricts behaviour. Out of all that could have been selected arises the constancy of what von Foerster calls a Gegenstände, an object that stands against its observer.

Play Orbit contributor Victor Newsome's fictional account of a young girl playing with a doll whilst observed by her mother describes just such a complex system. The unreconstructed gendering of Newsome's example notwithstanding, this 'toy situation' shows clearly how players are entangled in contingent relations to one another and how the object of play, the doll, stabilizes through their recurrent observations in play. Only then does the doll become, to return to Reichardt's fourpart definition of a toy, a 'depository for the imagination' and an object 'with which we can simulate real-life situations' ${ }^{82}$

With constructional toys, too, players must find out what a toy does or how it will perform as an object that constrains behaviour. They enter into this performative relation with a toy without the need to understand its 'internal mechanisms', which makes the toy, either in whole or in part, a Black Box. For Pickering, cybernetics has a Black Box ontology. To explain this ontology, Pickering takes, from Ashby's An Introduction to Cybernetics of 1958, the example of a doorknob. ${ }^{83} \mathrm{~A}$ child trying a doorknob learns to match input (her manipulation of it) to output (release of the latch) without seeing or understanding the internal mechanism. The doorknob is a Black Box, Ashby writes, 'whose internal mechanisms are not fully open to inspection'. The concept of a Black Box, which arose to describe problems in electrical engineering, extends to any systemic entity that performs some task by means largely obscure to an observer. To paraphrase Ashby, when faced with a Black Box, the question 'What 
9 Gordon Fletcher,

Wobbler, 1969. Mixed media construction operated by a motor, base 30 in diameter $x$ $76 \times 46 \mathrm{~cm}$. Jasia Reichardt and Peter Jones, Play Orbit, exhibition catalogue, Studio International, special issue, 1969/70, 152.

\section{Cardiff College of Art \\ Bouncing paddle \\ Ken Murcott and Dick Taylor \\ Versical poddle wheel turned by an an cunem producad by a boliows. The bellows pump an when a child bounces abovt on a spring-loaded sast tacing tom padele. The tor is designed for on infant of accromi matoly 14 to 20 months whose main strength is in tis lagt. making use of hi\} weight to comeress the bellowe. The vesuid expeniences to bo enioyed ave \\ the movemant of the chld in es envitan-

$$
\text { ment. }
$$ \\ the rotation of the paddis whes: \\ the intarchangesbilizy of poddle wheots \\ the colous ard patmins on the pediles \\ Cenaf cotion a dat

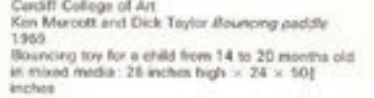

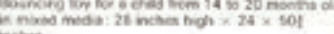

\section{Wobbler}

\section{Gordon Fletcher}

The pisce has a shallow whine die-shaped base, with a concene usper surface, an heoporating a trip mechanism. The ma pant comists of two shary rod fibreglass hemusphores, assembisd into as sphere, with a strip of back soam sekarat mo them. Frot this strop amerge a number ef black flexidte forms coratructed tiom pano wre, nubber tube, and poivrour resin

The trip mechaniam caves the sphere to pet every few mintos, causing the flenibla forms no sway aboue
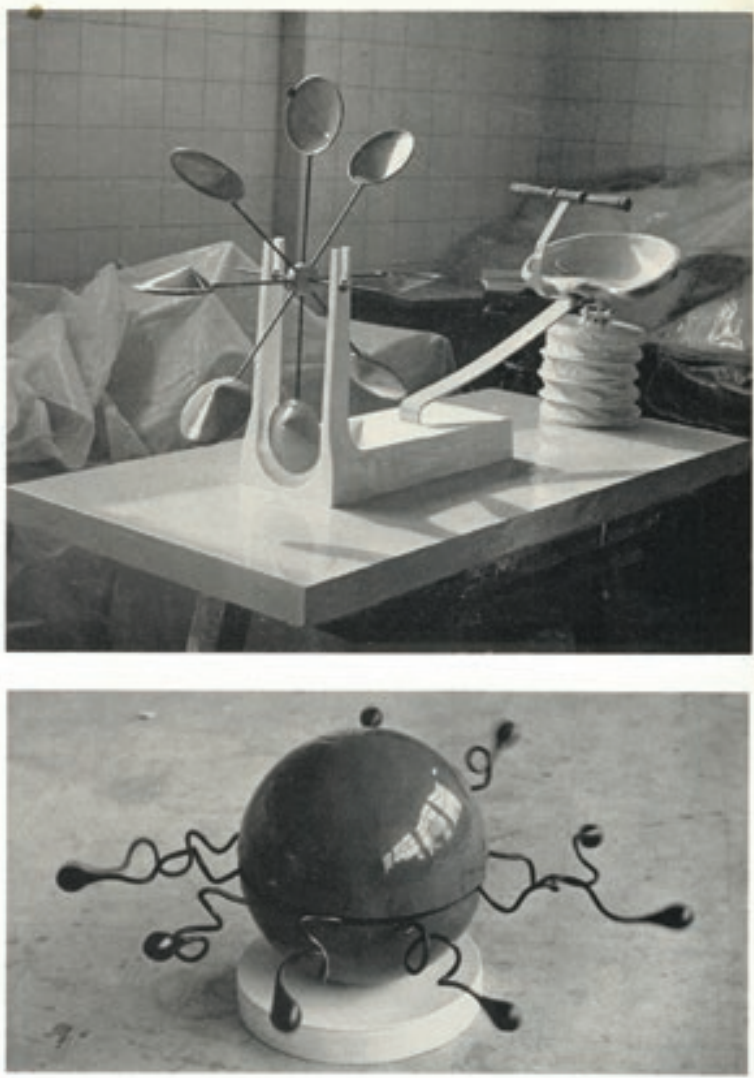

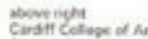

Coodon Ploge of An

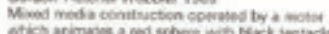

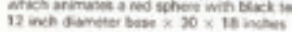

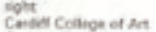

condon twether, dimereg for wocoto

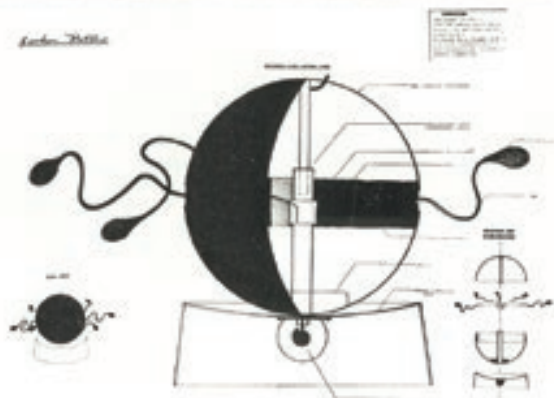

152

is in it?' becomes redundant. Other questions are more pressing, such as 'How should an observer proceed?' 'Which elements of the Box are discoverable and which are not?' 'What methods can be used to investigate the Box?' In Ashby's view, aside from its infamous, if somewhat overstated, relationship with systems of technocratic administration and surveillance, the most important aspect of cybernetics is that it 'tries to address the problematic of getting along performatively with systems that can always surprise us' ${ }^{84}$ In doing so, an experimenter couples herself to the Box 'so that the two form a system with feedback' (87). Perhaps the only way to engage the unpredictability of a Black Box, what mathematician René Thom called its 'catastrophe', is to play with it. ${ }^{85}$

A toy might be an exemplary Black Box. Charles Baudelaire's essay 'Morale du joujou' (1856), republished in full in the Play Orbit catalogue, suggests how. 'The child twists and turns his toy', Baudelaire writes, 'scratches it, shakes it, bumps it against the walls, throws it on the ground', and in doing so displays a 'first metaphysical 
10 Film still from footage of Play Orbit exhibition, showing children playing with Gordon Fletcher, Wobbler. Pathé 3328.05. tendency'. However, when the child at last opens it up and asks herself 'But where is the soul?', so begins 'stupefaction and sorrow' ${ }^{86}$ In order to avoid the onset of these emotions, the player learns to leave the Black Box closed enough that the system of Box and player might retain its soul.

For example, in the Pathé footage, two children appear to risk 'stupefaction and sorrow' as they play with Gordon Fletcher's Wobbler (plate 9), a sphere with 'black tentacles' which wobbled when a trip mechanism was activated. The children roughly spin Wobbler upon its base so that its two hemispheres begin to separate (plate 10). They pay no heed to Fletcher's wish that the trip mechanism would cause the tentacles to 'jolt every few minutes', and obviously have little knowledge of Wobbler's internal mechanism. ${ }^{87}$ Wobbler fails to be 'self-instructional', yet still the two children enter into a performative relation with it and will continue to do so as long as they do not open it up to discover its 'soul'.

Wobbler's treatment shows that, as a toy, the status of the Black Box becomes particularly precarious and its soul can be placed under stress, if not eradicated. Yet playing with such Black Boxes also might involve what Reichardt claimed for art: 'an act of transformation' that displayed emergent or even 'miraculous' properties without thereby depending on miracles or metaphysical explanations ${ }^{88}$ Play Orbit took on this Black Box ontology with its introduction of toys and its address to members

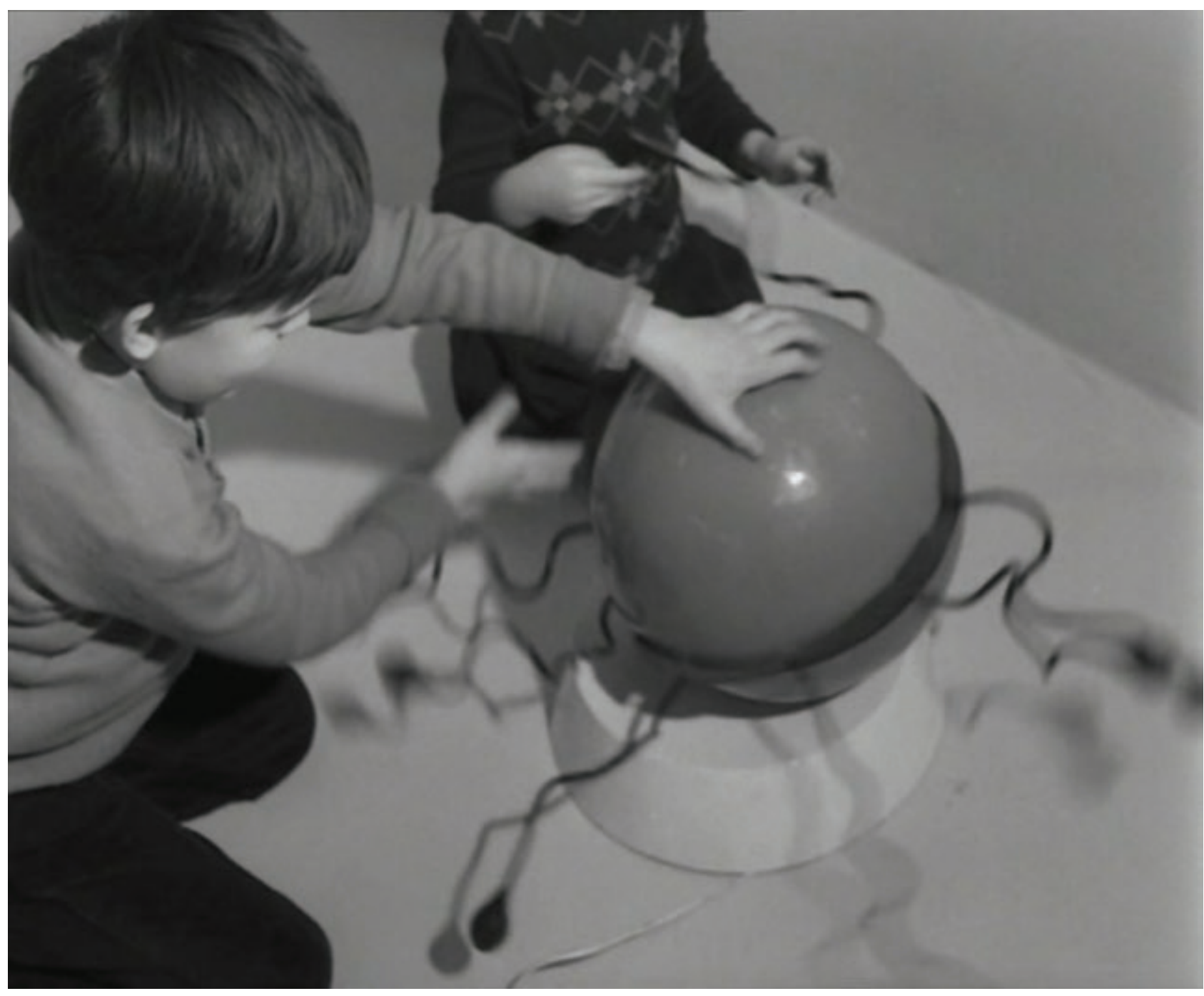


of an audience who must now test out what a toy does and what can be done with it in order to 'get along' with the unpredictable systems, the toys and environments, in which they take part.

\section{Conclusion}

There is enough in the historical record to discount Reichardt's doubts and to identify Play Orbit as a significant moment in the history of systems art that grew through the artistic encounter with cybernetics in the late 1960s. Its significance would be that it expands cybernetics beyond its initial applications in engineering, computing, and psychiatry, to include the domain of play.

Several cautionary notes have been made in recent scholarship with regard to emancipatory claims for participation in art during the late 1960s. On the one hand, Janet Kraynak has shown how between 1969 and 1974 Bruce Nauman built a number of extended sculptural installations that challenge the predominantly positive view of participation in the art-historical literature. Either as corrective to alienation, critique of authorship, or experimentation in collectivity, Kraynak argues, 'participation is seen as an interventionist gesture that furthers the ambitions of a progressive avant-garde'. ${ }^{89}$ By contrast, Nauman's installations presented participation as a strange, dependent, and decidedly not ludic situation. Drawing on the work of sociologist Alain Touraine, Kraynak suggests that these works are a response to the emergence of a technocratic society in which participation is a dominant mode of control and alienation.

On the other hand, even where participation was ludic, and even, on occasion, chaotic and destructive, as Floe has shown in her study of three events from the period, there was a 'persistence of spectatorial norms even in their proclaimed absence', and participation was, if not fully controlled, then at least planned and managed through play. ${ }^{90}$ Floe criticizes the promotion of play at the time as 'a lawless sphere of freedom and authenticity', and demands a 'more nuanced understanding of [play's] social, contextual, rule-bound and performative aspects. ${ }^{91}$

Play Orbit merits neither of these criticisms. In this instance, cybernetics does not simply apply to technocratic communication and control, built upon 'efficient interaction' and rightly criticized by the likes of Kraynak. ${ }^{92}$ Nor, as a counter to technocracy, does Play Orbit idealize play. The performative aspect of play participation shown by Play Orbit, which Reichardt described, in good faith, as the 'most democratic exhibition ever held in this country', was neither lawlessly free nor technocratic. Its Black Boxes consisting of many loose parts were played with and tested, and could be engaged only through a performative relationship between toy and players. This ontological change allowed Play Orbit to test out modes of sociability, in response to the problems of organization outlined above. In doing so, it extended cybernetics into the social fabric, and for this reason should be viewed as a significant moment in the encounter between art and cybernetics at the very end of the 1960s.

\section{Notes}

1 Jasia Reichardt, introduction to Play Orbit: Showing at Royal National Eisteddfod of Wales, Flint, 4-9 August 1969, Institute of Contemporary Arts, London, 28 November 1969-15 February 1970, London, 1969, 7.

2 See Francis Halsall, Systems of Art: Art, History and Systems Theory, Oxford, 2008; Luke Skrebowski, 'All systems go: Recovering Hans Haacke's systems art', Grey Room, 30, Winter 2008, 54-83; Pamela Lee, Chronophobia: On Time in the Art of the 1960s, Cambridge, MA, 2004; and Eve Meltzer, Systems We Have Loved: Conceptual Art, Affect, and the Anti-Humanist
Turn, Chicago, IL, 2013. The panels Expanding Systems Aesthetics at the Society for Literature, Science and the Arts annual conference of 2015, and Mapping Cybernetic Art: A Supra-Computational Approach at the Association of Art Historians 2016 annual conference continued this expanded approach.

3 See Hilary Floe, “"Everything was getting smashed”: Three case studies of play and participation, 1965-1971', Tate Papers, 22, Autumn 2014, unpaginated.

4 Reichardt, introduction to Play Orbit, 7. 
5 Reichardt, introduction to Play Orbit, 7.

6 Jonathan Benthall, 'Technology and art 10: Linguistics and toys at the ICA', Studio International, 179: 918, January 1970, 8.

7 Peter Hobbs in Play Orbit, 123.

8 Roy Grayson and Jasper Sewett in Play Orbit, 119, 127.

9 Robert Morris, 'Notes on sculpture, Part 3: Notes and non-sequiturs', Artforum, 5: 10, June 1967: 24-9, reprinted in R. Morris, Continuous Project Altered Daily, Cambridge, MA, 1993, 23.

10 Bernard Bertschinger and Edwina Leapman in Play Orbit, 111, 128.

11 Juliet Brightmore, letter to contributing artists, undated, Tate Gallery Archive (TGA) 955/7/2/18.

12 ICA press statement, Play Orbit: An exhibition of toys, games, and playables by artists in Britain, June 1969. Press release for Barry Smith's Theatre of Puppets, 20 to 24 January 1970, TGA 955/7/2/18.

13 Andrew Pickering, The Cybernetic Brain: Sketches of Another Future, Chicago, IL, 2010.

14 Jasia Reichardt, 'Cybernetics, art and ideas', in J. Reichardt, ed., Cybernetics, Art and Ideas, Greenwich, CT, 1971, 11.

15 Maria Fernandez, 'Detached from HiStory: Jasia Reichardt and cybernetic serendipity', Art Journal, 67: 3, Fall 2008, 23.

16 Leslie Stack quoted in Linda Talbot, 'Meet the friendly robots', Hampstead and Highgate Express, 26 July 1968. For a critical assessment of the media reception of Cybernetic Serendipity, see Rainer Usselmann, 'The dilemma of media art: Cybernetic Serendipity at the ICA London', Leonardo, 36: 5, 2003: 389-96.

17 Jasia Reichardt, email correspondence with the author, 16 October 2015.

18 Roy Ascott, 'Behaviourist art and the cybernetic vision', in Edward Shanken, ed., Telematic Embrace: Visionary Theories of Art, Technology and Consciousness, Berkeley, CA, 2003, 111. Originally published in two parts in Cybernetica: Journal of the International Association for Cybernetics, 9 , 1966 and, 10, 1967.

19 Ascott, 'Behaviourist art and the cybernetic vision', 127. Ascott later develops the idea of a Cybernetic Art Matrix that constituted a 'stance ... a general set of attitudes to human behaviour and a particular concrete behavioural situation'. Ascott, 'The cybernetic stance: My process and purpose', Leonardo, 1: 2, April 1968, 105.

20 Ascott, 'Behaviourist art and the cybernetic vision', 110.

21 Roy Ascott, letter to the Editor, Studio International, 175, July/August 1968, 8. Reichardt, correspondence with Peter Jones, 9 October 1968, TGA 955/7/2/17

22 Michael J. Apter, 'Cybernetics and art', Leonardo, 2: 3, July 1969, 257.

23 Jasia Reichardt, 'A perspective of kinetic art', Studio International, 173: 886, February 1967, 59

24 Apter, 'Cybernetics and art', 263.

25 Jasia Reichardt, 'Patronage and patrons', Studio International, 173: 887, March 1967, 115

26 Apter, 'Cybernetics and art', 263.

27 Apter, 'Cybernetics and art', 264.

28 Jasia Reichardt, The Computer in Art, London, 1971, 89. Apter, 'Cybernetics and art', 262.

29 Reichardt, The Computer in Art, 89.

30 Judith Rodenbeck, Radical Prototypes: Allan Kaprow and the Invention of Happenings, Cambridge, MA, 2011.

31 Reichardt, The Computer in Art, 35.

32 Michael Baxandall, Patterns of Intention: On the Historical Explanation of Pictures, New Haven, CT and London, 1985, 42.

33 Bruce Clarke, 'From information to cognition: The systems counterculture, Heinz Von Foerster's pedagogy, and second-order cybernetics', Constructivist Foundations, 7: 3, 2012, 197.

34 Alastair Best, 'When attitudes become toys', Design, 252, December 1969, 24.

35 Play Orbit Exhibition 1970, black and white, mute, 4 minutes, 35 seconds, British Pathé archive 3328.05.

36 Ian Hunter, statement in Play Orbit, 156

37 Ron Dutton, statement in Play Orbit, 114

38 Harald Szeemann, 'Zur Ausstellung', in Live In Your Head: When Attitudes Become Form, Bern, 1969, unpaginated.

39 Germano Celant, 'A readymade: When attitudes become form', in When Attitudes Become Form, Bern 1969/Venice 2013, Milan, 2013, 389.

40 Brandon Taylor, Art for the Nation: Exhibitions and the London Public 1747-2001, New Brunswick, NJ, 1999, 228-9.
41 Reichardt, 'Non-games', Studio International, 175: 898, March 1968, 110.

42 Reichardt, 'Art and usefulness,' Studio International, 175: 901, June 1968, 290.

43 See Simon Nicholson, 'Structure for self-instruction', Studio International, 175: 901, June 1968, 291-2.

44 Simon Nicholson, statement in Play Orbit, 136

45 Simon Nicholson, 'The theory of loose parts: An important principle for design methodology', Studies in Design Education, Craft, and Technology, 4: 2, 1972, 5-6.

46 Nicholson, 'The theory of loose parts', 11.

47 See Frank Oppenheimer, 'The Exploratorium: A playful museum combines perception and art in science education', American Journal of Physics, 40: 7, July 1972, 978-84.

48 Nicholson, 'The theory of loose parts', 13. On the Morris retrospective at the Tate, see John Bird, 'Minding the body: Robert Morris's 1971 Tate Gallery retrospective', in J. Bird, and M. Newman, eds, Rewriting Conceptual Art, London, 1999; Dorothea von Hantelmann, 'On the socio-economic role of the art exhibition', in Juan Gaitán, Nicolaus Schafhausen, and Monika Szewczyk, eds, Cornerstones, Rotterdam, 2011. On its restaging at Tate Modern in 2009, see Tim Stott, 'Lessons in playing: Robert Morris' Bodyspacemotionthings 2009 as a biopolitical environment', in Malcolm MacLean, Wendy Russell and Emily Ryall, eds, Philosophical Perspectives on Play, London, 2015.

49 Michael Kustow, letter to Francis Hawcroft, 26 February 1969, TGA 955/7/2/18.

50 Jasia Reichardt, 'Cybernetics, art, and ideas', in J. Reichardt, ed., Cybernetics, Art, and Ideas, Greenwich, CT, 1971, 11

51 A list of the invitees and their responses accompanied a letter from Reichardt to Valmai Ward, Administrative Assistant at the Welsh Arts Council, 28 October 1968, TGA 955/7/2/17.

52 Michael Punt, 'Play Orbit: A play on the history of play', Technoetic Arts: A Journal of Speculative Research, 6: 2, 2008, 139.

53 Lisa Tickner, Hornsey 1968: The Art School Revolution, London, 2008, 51.

54 See Stanley Matthews, 'The Fun Palace: Cedric Price's experiment in architecture and technology', Technoetic Arts: A Journal of Speculative Research, 3: 2, 2005, 73.

55 Roy Landau, New Directions in British Architecture, London, 1968, 76.

56 Jasia Reichardt, 'Art is big, round, and good', Studio International, 174: 892, September 1967, 81.

57 Reichardt, 'Art is big, round, and good', 81.

58 Reichardt, 'Art is big, round, and good', 81.

59 Pask's organizational diagram for the Fun Palace, which shows this transformation, is discussed and reproduced in Pickering, The Cybernetic Brain, 368-9.

60 Jack Burnham, 'Systems esthetics', Artforum, 7:1, September 1968, 31.

61 'Such is our ideal - not another museum, another bleak exhibition gallery, another classical building in which insulated and classified specimens are displayed for instruction, but an adult's play centre, a workshop where work is a joy, a source of vitality and a daring experiment. We may be mocked for our naïve idealism, but at least it will not be possible to say that an expiring civilization perished without a creative process.' Read, introduction to 40 Years of Modern Art, 1947 TGA 955/1/12/10.

62 Typescript (September 1948) of introduction to exhibition catalogue for 40,000 Years of Modern Art: A Comparison of Primitive and Modern, held at Academy Hall, Oxford St., London, 20 December 1948 to 29 January 1949, TGA 955/1/12/10.

63 Herbert Read, Education Through Art, London, 1943, 110.

64 David Thistlewood, 'The Independent Group and art education in Britain 1950-1965', in David Robbins, ed., The Independent Group: Postwar Britain and the Aesthetics of Plenty, Cambridge, MA, 1990, 213.

65 John Berry, Richard Horden, statements for Play Orbit, 110, 124.

66 'The terrible challenge of leisure', New Statesman, 66, 23 August 1963, 1

67 Herbert Read, 'Atrophied muscles and empty art', New Scientist, 391, 14 May 1964, 429.

68 Sebastian de Grazia, Of Time, Work and Leisure, New York, 1962.

69 John Berry, statement for Play Orbit, 110.

70 David Thistlewood, Herbert Read: Formlessness and Form: An Introduction to His Aesthetics, London, 1984, 126.

71 Quoted in Benthall, 'Technology and art 10', 7.

72 See Fernandez, 'Detached from HiStory', 10. 


\section{Tim Stott}

73 W. Ross Ashby, transcript of the lecture 'Art and Communication Theory' delivered at ICA on Thursday 7 April 1960, TGA 955/1/7/30.

74 Reichardt, 'Art and usefulness', 291.

75 Usselmann, 'The dilemma of media art'.

76 N. Katherine Hayles, How We Became Posthuman: Virtual Bodies in Cybernetics, Literature, and Informatics, Chicago, IL, 1999, 3.

77 Hayles, How We Became Posthuman, 4.

78 Fernandez, 'Detached from HiStory', 8.

79 Alun and Elizabeth Evans in Play Orbit, 115

80 Lynn Segal, The Dream of Reality: Heinz von Foerster's Constructivism, New York, 1986, 142.

81 Heinz von Foerster, 'Objects: Tokens for (eigen-)behaviours', in Understanding Understanding: Essays on Cybernetics and Cognition, New York, 2003, 261.

82 Victor Newsome, 'Chop', Play Orbit, 132.

83 Pickering, The Cybernetic Brain, 23.

84 W. Ross Ashby, An Introduction to Cybernetics, London, 1958, 86.

85 René Thom, 'At the boundary of man's power: Play', SubStance, 8: 4, 1979, 12.

86 Charles Baudelaire, 'Morale du joujou' (1853), in Oeuvres complètes, Volume 1, Paris, 1975, 587.

87 Gordon Fletcher in Play Orbit, 152.

88 On the 'miraculous' properties of incompletely observable systems, see Ashby, Introduction to Cybernetics, 114.

89 Janet Kraynak, 'Dependent participation: Bruce Nauman's environments', Grey Room, 10, Winter 2003, 24.

90 Floe, “"Everything was getting smashed”, unpaginated.

91 Floe, “"Everything was getting smashed”'.

92 Kraynak, 'Dependent participation', 37 